\title{
7. PROVENANCE OF MIOCENE SANDSTONES FROM SITES 796, 797, AND 799, JAPAN SEA ${ }^{1}$
}

\author{
Sam Boggs, Jr., ${ }^{2}$ and Abbas Seyedolali ${ }^{2}$
}

\begin{abstract}
Deep drilling in the Japan Sea during Legs 127 and 128 resulted in recovery of volcanic lithic sandstones from Leg 127, Sites 796 and 797, and feldspathic sandstones from Leg 128, Site 799. Petrographic and geochemical analyses of sandstone framework grains define source-rock lithology and the tectonic setting of the source areas that furnished the framework constituents of these sandstones. Our analyses indicate that upper Miocene sandstones from Site 796 in the northeastern part of the Japan Basin were derived from a dominantly pyroclastic volcanic source or sources that lay in an undissected magmatic arc on or near southwestern Hokkaido, Japan. Lower Miocene sandstones from Site 797, located in Yamato Basin southeast of Yamato Rise, were also derived mainly from a volcanic source area. This source area lay in an undissected to transitional magmatic arc that was probably located in west-central Honshu, Japan, and that included some metamorphic, sedimentary, and plutonic source rocks. Lower Miocene sandstones at Site 799, which lies in the southwestern end of Kita-Yamato Trough on Yamato Rise, were derived primarily from granitic source rocks. Volcanic, metamorphic, and sedimentary source rocks also furnished detritus to this site. The principal source of sediment for Site 799 sandstones was probably the granitic and sedimentary rocks of Kita-Yamato Bank, which lies nearby to the west of Site 799 on Yamato Rise. Minor amounts of volcanic detritus, which was probably shed from Yamato Bank east of Site 799, also reached Site 799. The sandstones from Sites 796, 797, and 799 were deposited at upper to middle bathyal depths by turbidity currents.
\end{abstract}

\section{INTRODUCTION}

A major objective of Leg 127 drilling in the Japan Sea was to determine the age and nature of acoustic basement. Therefore, basinal locations were selected for drilling in areas where the sediment column would likely be free from thick sections of PlioceneQuaternary terrigenous sediments. Leg 128 drilling was also planned on high-standing blocks (Shipboard Scientific Party, 1990a, p. 16). Because of the location of Leg 127 and 128 drill sites in basin-flank positions, sands and sandstones were encountered at only three of the six sites drilled during Leg 127 and 128 (Fig. 1). Thin, scattered sand and sandstone that range in age from late Miocene to late Pliocene are present in cores from Site 796 in the Japan Basin off southern Hokkaido (Fig. 2). Thicker sandstone units of early Miocene(?) age are present at Site 797 in the Yamato Basin and Site 799 on Yamato Rise.

Samples of sand and sandstone from Sites 796 and 797 were obtained by the senior author during shipboard sampling on Leg 127. Sandstone samples from Site 799 were subsequently provided by the curator, Ocean Drilling Program, Texas A\&M University. These sandstone samples were analyzed by petrographic and electron- microprobe techniques to determine framework mineralogy and chemical composition of feldspars. This paper focuses on sandstone compositions (detrital modes) and feldspar compositions as a basis for provenance interpretation. The purpose of the paper is provide an interpretation of the source rocks that furnished sands to these Japan Sea sites, and to evaluate the probable tectonic setting and location of the source areas. This information should help to characterize the sedimentation and oceanographic evolution of the Japan-Sea region, which is one of the goals of ODP drilling in the Japan Sea. A discussion of diagenetic modification in Sites 796, 797, and 799 sandstones, which can affect provenance interpretation, is given elsewhere in this volume (Boggs and Seyedolali, this volume).

\footnotetext{
${ }^{1}$ Pisciotto, K. A., Ingle, J. C., Jr., von Breymann, M. T., Barron, J., et al., 1992. Proc. $O D P_{1}$ Sci. Results, 127/128, Pt. 1: College Station, TX (Ocean Drilling Program). U.S.A.

${ }^{2}$ Department of Geological Sciences, University of Oregon, Eugene, OR 97403 ,
}

\section{PREVIOUS WORK}

The petrographic data presented and discussed in this paper are the first data to be reported for Miocene sandstones of the Japan Sea, as Miocene sandstones were not recovered during previous DSDP drilling in the Japan Sea. Previous petrologic research on Japan Sea sediments has focused mainly on Quaternary sediments. For example, Sibley and Pentony (1978) studied Quaternary turbidite sands from DSDP Leg 31, Sites 299 and 301 (see Fig. 1). They report that sediments from Site 299 in the Yamato Basin contain less quartz, more total feldspar, more plagioclase, and less alkali feldspar than do sediments from Site 301 in the Japan Basin.

They conclude that these differences arose because Site 299 received most of its sediments from central Japan through the Toyoma Trough, whereas Site 301 received sediments both from the Asian mainland and from the Japanese arc. Packer and Ingersoll (1986) reexamined the provenance of Quaternary sediments from DSDP Sites 299 and 301 . They conclude that Site 301 contains more quartz, a higher content of sedimentary rock fragments (as a percentage of total rocks), and a lower content of volcanic rock fragments than Site 299 because it received sediments from the Asian mainland as well as the island of Honshu. Boggs (1984) studied the characteristics of Quaternary sediments in piston cores and DSDP cores from the Japan Sea. He demonstrated that mud turbidites and hemipelagic muds are predominant in the Quaternary sediments along the eastern side of the Japan Sea whereas sand-silt turbidites and hemipelagic muds are more common along the western side. This study did not examine the petrographic characteristics or provenance of the sands.

\section{METHODS}

More than 80 samples of sand, silt, and sandstone and siltstone from Sites 796 and 797, and 23 samples of sandstone from Site 799, were obtained for provenance analysis. Sandstone samples selected for petrographic analysis were impregnated with epoxy before preparing thin sections. The thin sections were stained for potassium feldspars using the technique of Houghton (1980). Fourteen samples from Site 796, 46 samples from Site 797, and 10 samples from Site 799 were analyzed petrographically by point counting (Appendix). 


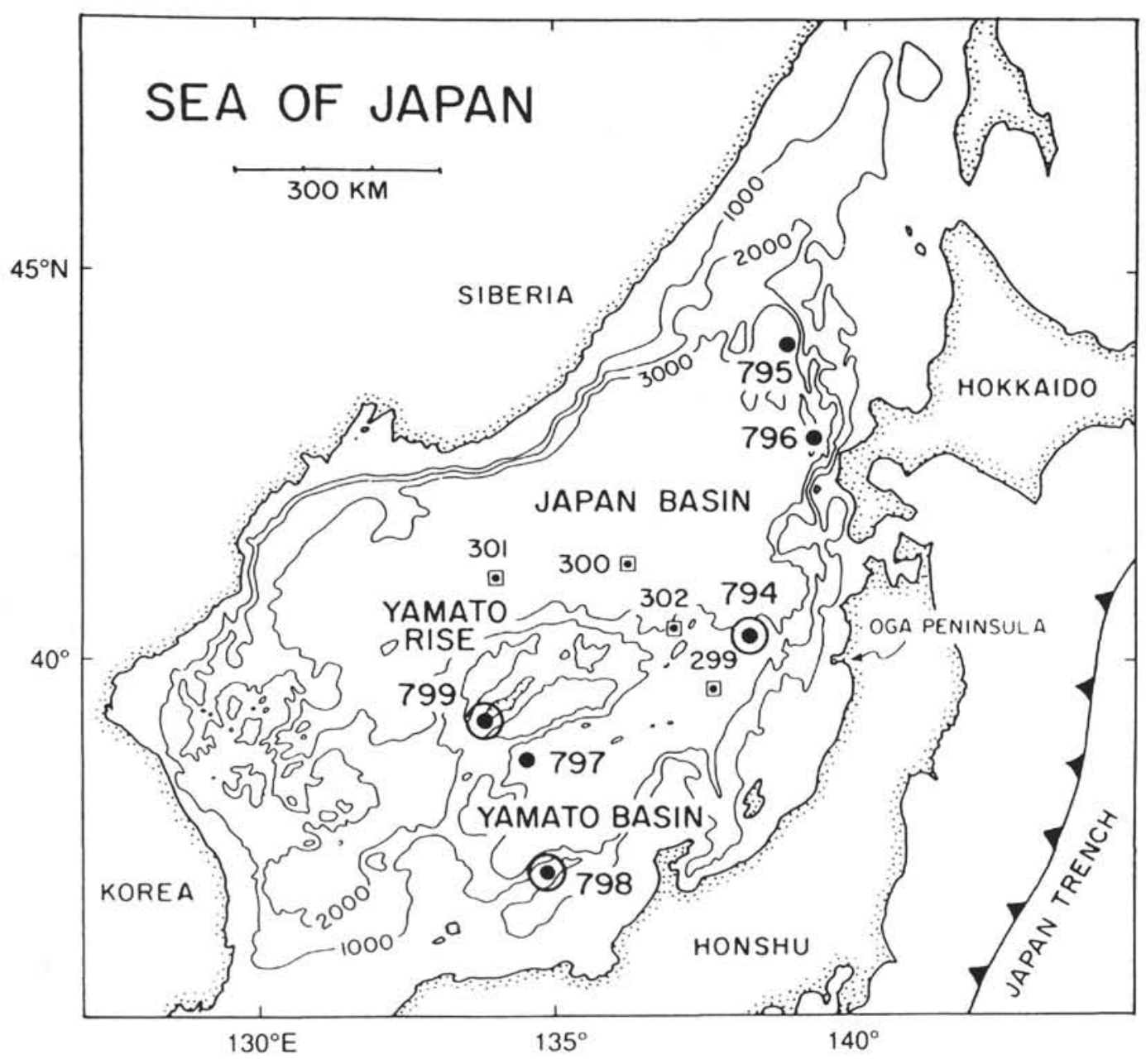

Figure 1. Location map of the Japan Sea showing drill sites for Leg 127 (dots) and Leg 128 (circled dots). Sites 796, 797, and 799 are the focus of this paper. Boxed dots are DSDP sites, drilled in 1975 (from Shipboard Scientific Party, 1990b, Fig. 2, p.7).

At least 500 points were counted in each thin section. The conventional point-counting technique (Suttner and Basu, 1985) was used rather than the so-called Gazzi-Dickinson method (Ingersoll et al., 1984). That is, all rock fragments were counted as rock fragments. In the Gazzi-Dickinson method, monomineralic grains larger than $0.0625 \mathrm{~mm}$ that occur within larger rock fragments are counted as that crystal rather than as the larger rock fragment.

Twenty-seven polished sections of samples, selected from all three Japan Sea sites, were prepared for microprobe analysis. The chemical compositions of approximately 650 feldspar grains in these samples were determined with a CAMECA SX 50 Electron Probe Microanalyzer. Feldspar grains chosen for analysis included K-feldspars, if present, and A-twinned, C-twinned, untwinned, zoned, and unzoned plagioclase. Appropriate data-reduction techniques provided in the CAMECA SX 50 software were used to provide data output in the form of cation ratios and $\mathrm{Or}, \mathrm{Ab}, \mathrm{An}(\mathrm{K}, \mathrm{Na}, \mathrm{Ca})$ percentages.

\section{STRATIGRAPHIC AND DEPOSITIONAL CHARACTERISTICS}

The stratigraphic sections at Sites 796, 797, and 799 are shown in greatly generalized form in Figure 2 (see Fig. 1 for location). Finegrained sediment (silty clay and claystone, diatom ooze and diatom clay, siliceous claystone) dominates the lithology at all of the sites. Sandstone and tuff are distinctly subordinate rock types in terms of overall thickness and volume.
Sandstone or sand units at Site 796 do not exceed about $1 \mathrm{~m}$ in thickness and many are only a few centimeters thick. They occur throughout the stratigraphic section interbedded with sediments that range in age from late Miocene to Pliocene. The Pliocene sands are few, thin, and unconsolidated. They are not included in this study. Associated sediments include siltstones, silty clays and claystones, tuffs, and pebbly claystones. Grain size of the sandstones ranges from very fine grained to coarse, although fine-grained and mediumgrained sandstones are dominant. Many of the sandstones, including very thin units, display normal grading (Fig. 3). They are interpreted to be the deposits of sediment gravity flows (Shipboard Scientific Party, 1990c).

The sandstones at Site 797 are confined to stratigraphic units of early Miocene or older(?) age. They occur over an interval of about $400 \mathrm{~m}$ in the basal part of the section, where they are interlayered with altered basaltic sills and flows and silty claystones (Fig. 2). Units dominated by sandstone beds range from $<1 \mathrm{~m}$ to about $9 \mathrm{~m}$ in thickness; however, many individual sandstone beds are $<15 \mathrm{~cm}$ thick. The sandstones are dominantly fine-grained to mediumgrained. They typically display normal grading, internal cross- and planar-lamination, and sharp bases with load casts. Woody fragments and other carbonaceous material are commonly abundant. Many of the sandstone units show nearly complete Bouma sequences. The thin sandstone shown in Figure 4 illustrates many of these features. The characteristics of these sandstones suggest deposition by sediment gravity flows (Shipboard Scientific Party, 1990d). 


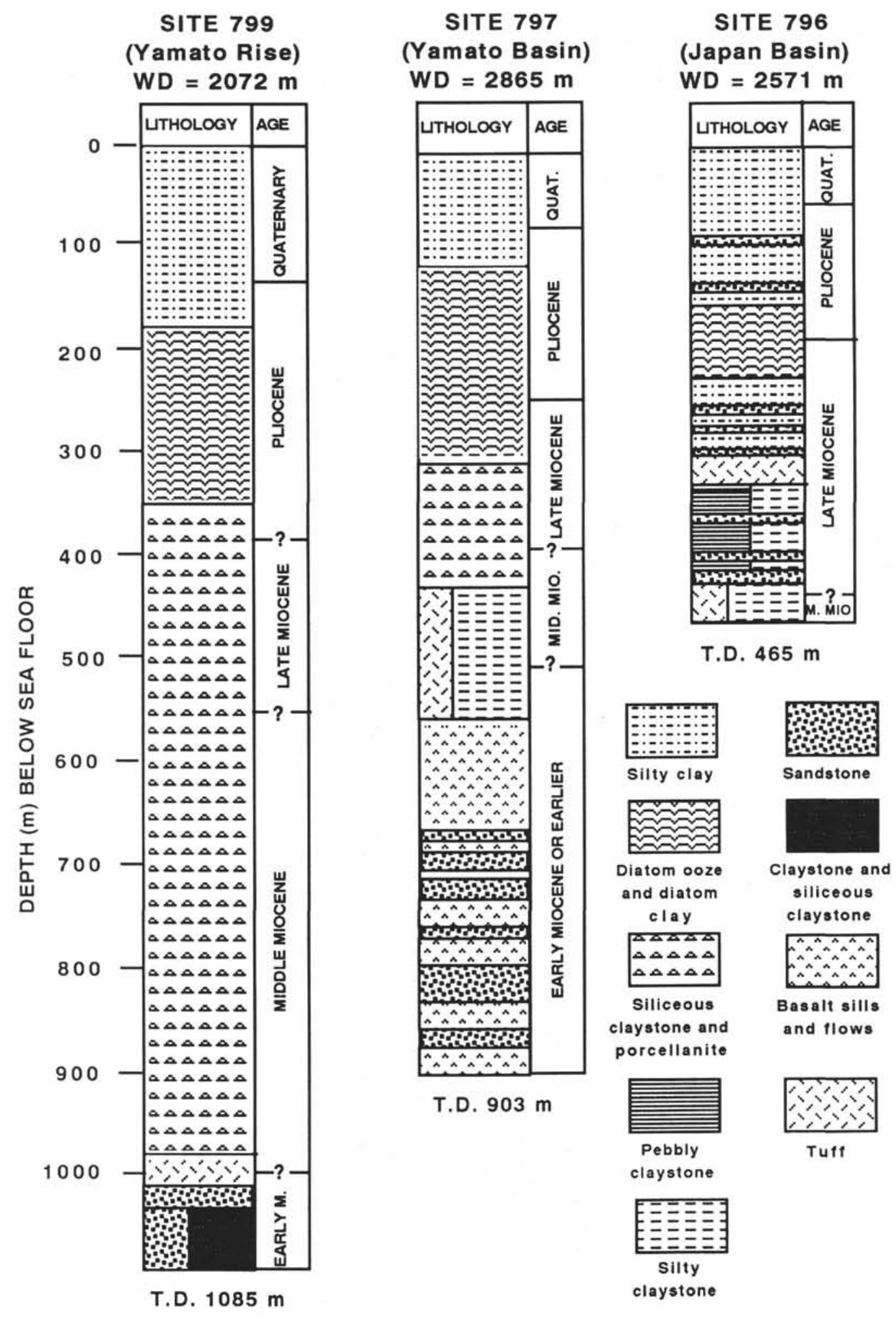

Figure 2. Generalized lithology of Miocene-Quaternary sediments at ODP Sites 796 (northeastern Japan Basin), 797 (Yamato Basin), and 799 (Yamato Rise) in the Japan Sea. 


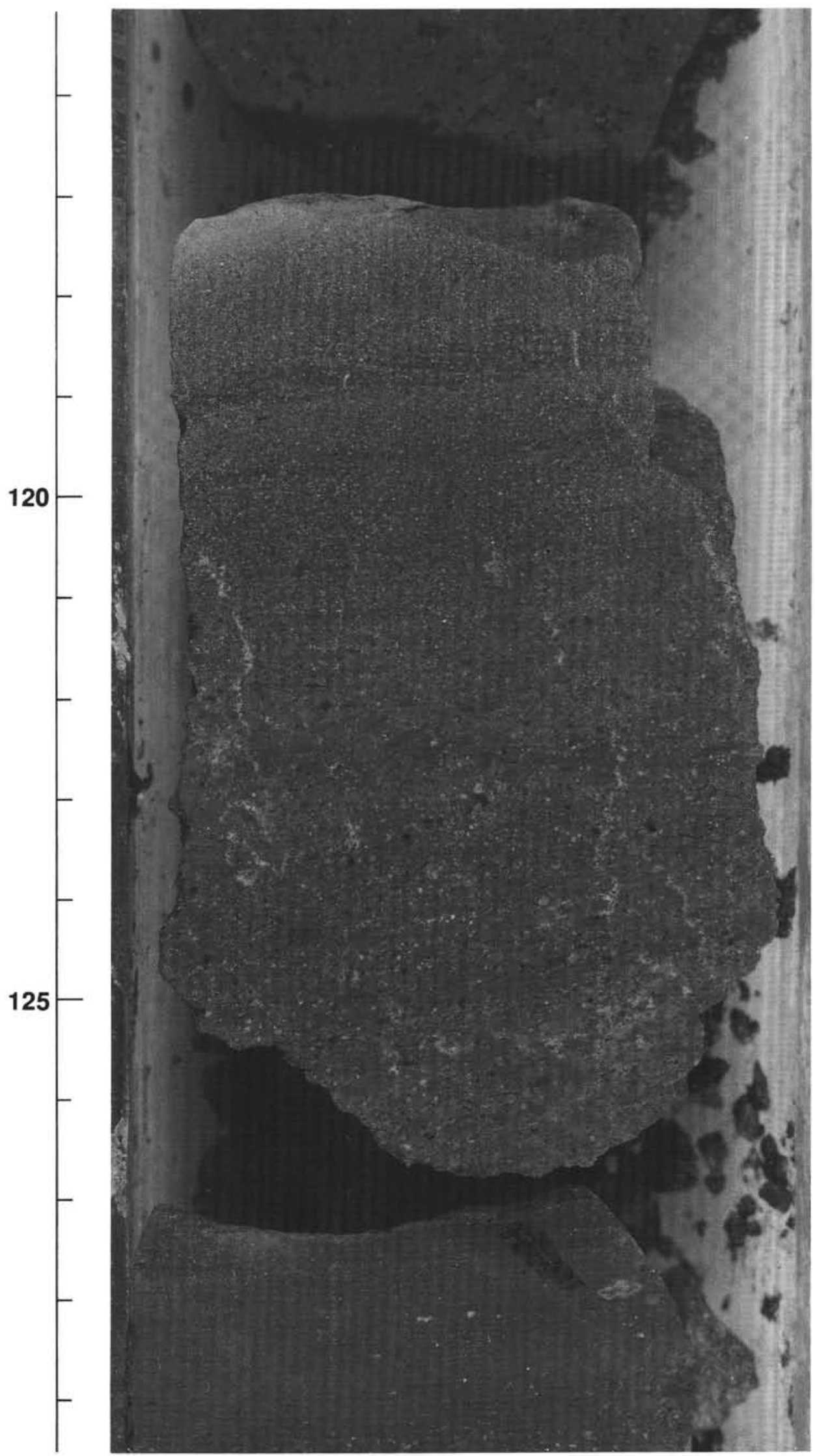

Figure 3. Normally graded volcaniclastic sandstone, Core 127-796B-22R, approximately $360 \mathrm{mbsf}$. 


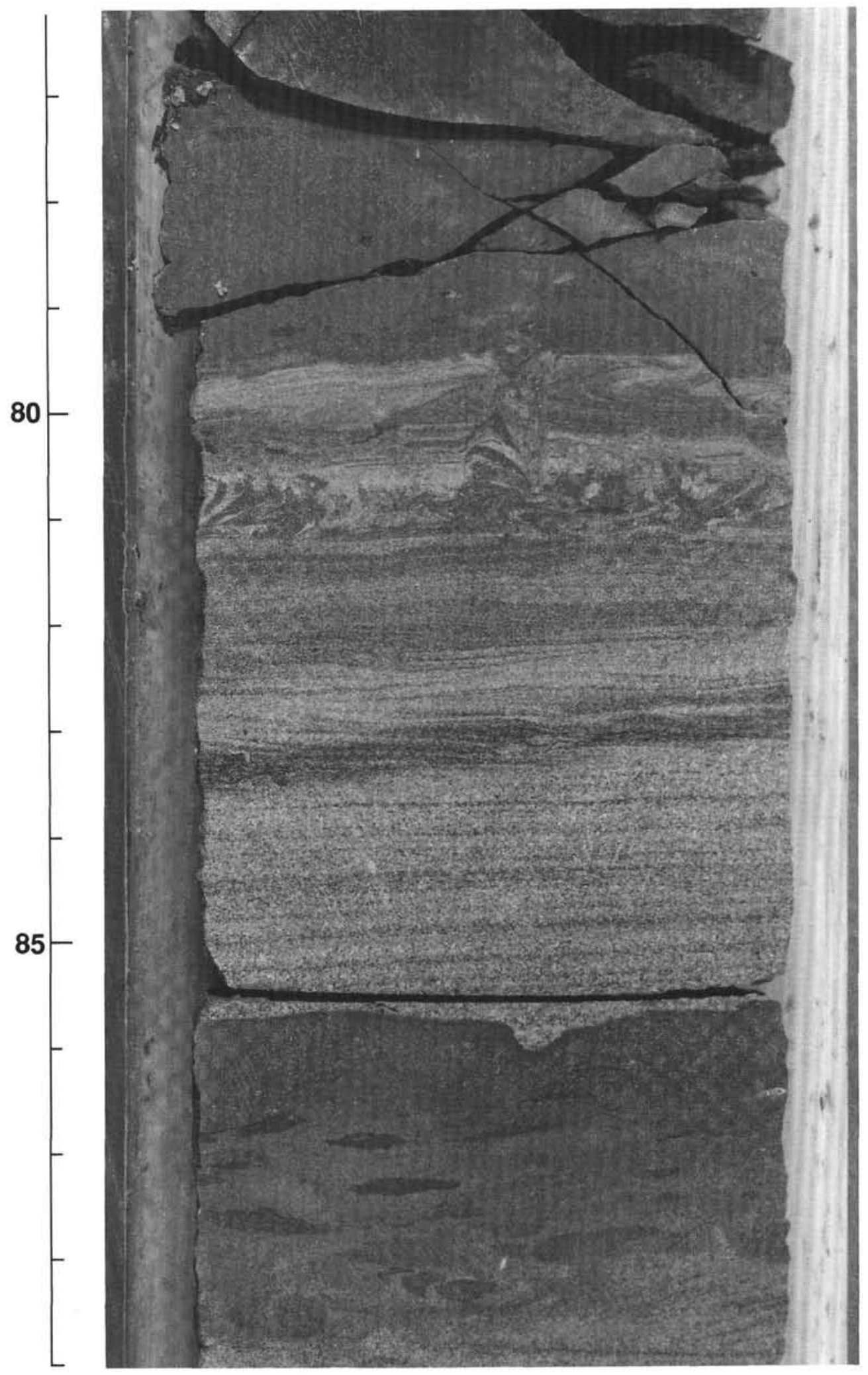

Figure 4. Normally graded volcaniclastic sandstone (light color) that displays a sharp basal contact and a load cast. The sandstone also shows internal planar-lamination and ripple cross-lamination. The upper part of the sandstone bed was deformed by sediment flow or squeezing prior to lithification. Core $127-797 \mathrm{C}-22 \mathrm{R}$, approximately $687 \mathrm{mbsf}$. 
At Site 799, sandstones are present only in the basal $65 \mathrm{~m}$ of the section in sediments of early Miocene age. The thickest sandstone unit is about $5 \mathrm{~m}$ thick. All other sandstone beds are less than $1 \mathrm{~m}$ thick, and many are only about $1 \mathrm{~cm}$ thick. The sandstones are interbedded with siliceous claystone and claystone. They range in grain size from very fine grained to coarse grained, and, like Site 797 sandstones, typically show normal grading, internal cross-lamination and planar-lamination, and sharp bases with load casts. Plant fragments are common constituents. Leg 128 shipboard scientists (Shipboard Scientific Party, 1990c) interpret these deposits as turbidites.

\section{PETROGRAPHY OF FRAMEWORK COMPONENTS}

\section{Framework Composition and Sandstone Classification}

The framework composition of Site 796, 797, and 799 sandstones is listed in the Appendix at the end of the paper. The average framework composition is summarized in Table 1. Sandstones from these sites display marked differences in composition of framework grains. Sandstones from Site 796, which is located in the northern part of the Japan Basin near Hokkaido (Fig. 1), are composed dominantly of volcanic rock fragments (Fig. 5), volcanic glass (Fig. 6), and plagioclase feldspars. These three constituents constitute about $90 \%$ of total framework grains and almost 99\% of QFR (quartz-feldspar-rock fragments) constituents. Quartz commonly makes up about $1 \%$ of the framework grains, and heavy minerals (mainly amphiboles and pyroxenes) make up about $2 \%$. Potassium feldspars are virtually absent. Rounded mudstone ripup clasts are common in the sandstones. These clasts appear to have been torn from the seafloor by the turbidity currents that emplaced the sandstones. They are included in Table 1 as part of the framework components; however, they do not have provenance significance. The compositions of framework grains in the Miocene sandstones at Site 796 do not display any trend with respect to depth below the seafloor (see Appendix).

Sandstones from Site 797, located in the Yamato Basin southeast of Yamato Rise (Fig. 1), contain considerably more quartz than do Site 796 sandstones. Quartz makes up about $10 \%$ of total framework constituents and about $13 \%$ of QFR constituents. Potassium feldspars, mainly sanidine, are also much more abundant, and constitute about $6 \%$ of framework grains. Plagioclase feldspars, volcanic rock fragments, and glass are less abundant than in Site 796 sandstones, but nonetheless are the dominant constituents in Site 797 sandstones. Micas (mainly biotite), detrital chlorite, heavy minerals, and plutonic, metamorphic, and sedimentary rock fragments are minor components of Site 797 sandstones. All except heavy minerals are more abundant in Site 797 sandstones than in Site 796 sandstones. Ripup clasts are also common in Site 797 sandstones.

Sandstones at Site 799 have a markedly higher content of quartz, potassium feldspars, and plutonic and sedimentary rock fragments than do Site 796 or Site 797 sandstones. Correspondingly, they have a strikingly lower content of volcanic rock fragments and glass. Quartz makes up about 36\% of total framework grains and $38 \%$ of QFR constituents. Potassium feldspars make up about $19 \%$ of total framework grains, and are composed mainly of orthoclase and microcline, much of which displays perthitic lamellae. By contrast, the K-feldspars at Site 797 are mainly sanidine. Table 1 shows that the plagioclase/total feldspar ratio in Site 799 sandstones is slightly lower than that in Site 797 sandstones, and is considerably lower than that in Site 796 sandstones. The extremely low content of volcanic rock fragments and glass (about 3 framework \%) in Site 799 sandstones has significance for provenance interpretation. Note that volcanic rock fragments and glass comprise about $98 \%$ of total rock fragments at Site 796 and about $90 \%$ at Site 797 , but only $19 \%$ of the total rock fragments at Site 799. The relatively high content of plutonic rock (granite) fragments at Site 799 is also significant for provenance interpretation.

The compositional differences among the sandstones from these three Japan Sea sites is strikingly displayed in Figure 7. In this figure, the QFR composition of the sandstones is plotted on Gilbert's (Williams et al., 1982 , p. 327) sandstone classification diagram. Note that ripup clasts (intraclasts) are included with detrital rock fragments in this classification. Nearly all of the sandstones from Sites 796 and 797 are lithic arenites or lithic wackes; they plot toward the lithic corner of the classification

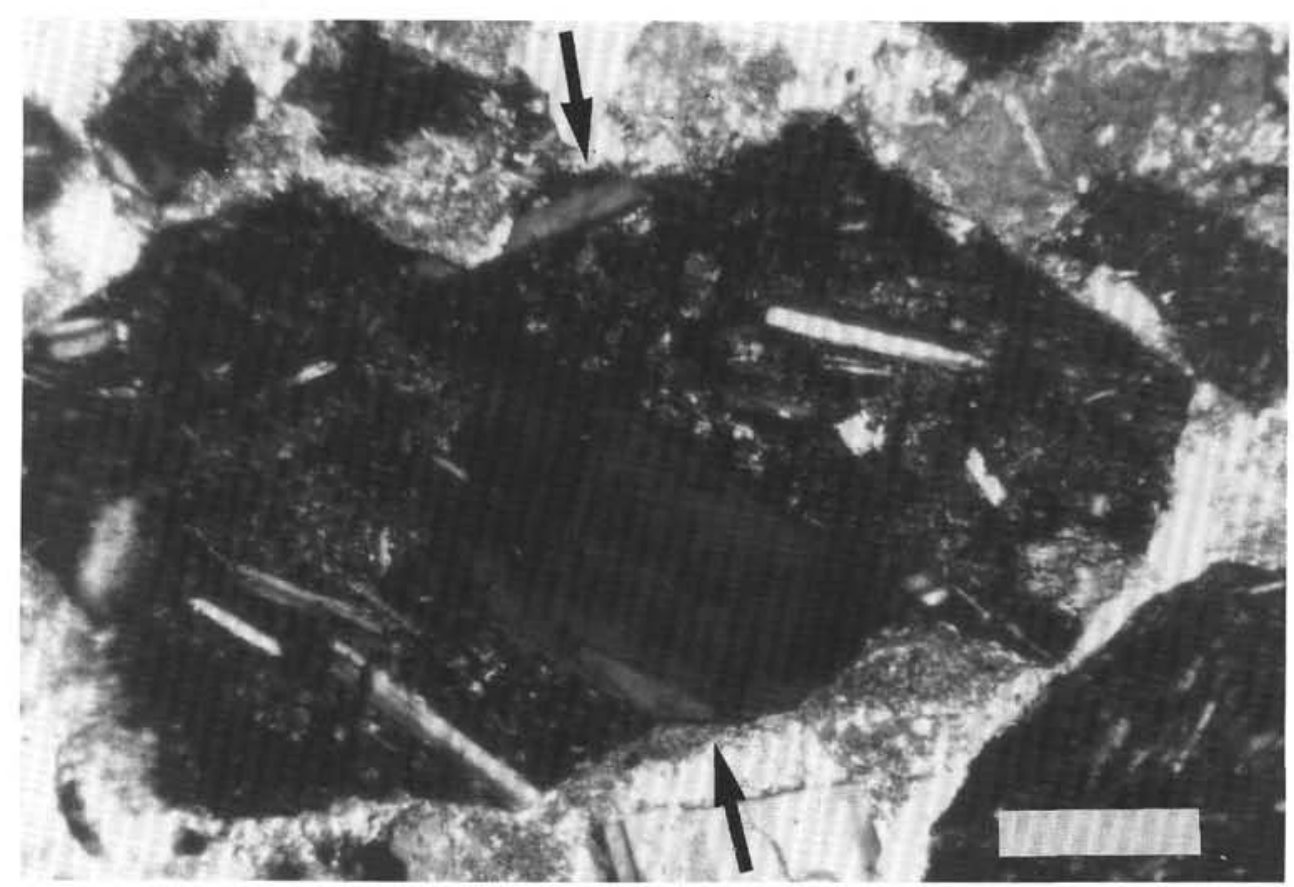

Figure 5. Glassy volcanic rock fragment (arrows) surrounded by mud matrix that has been replaced by carbonate; Core 127-796B-11R, approximately 253 mbsf. Crossed nicols. Scale bar $=0.1 \mathrm{~mm}$. 


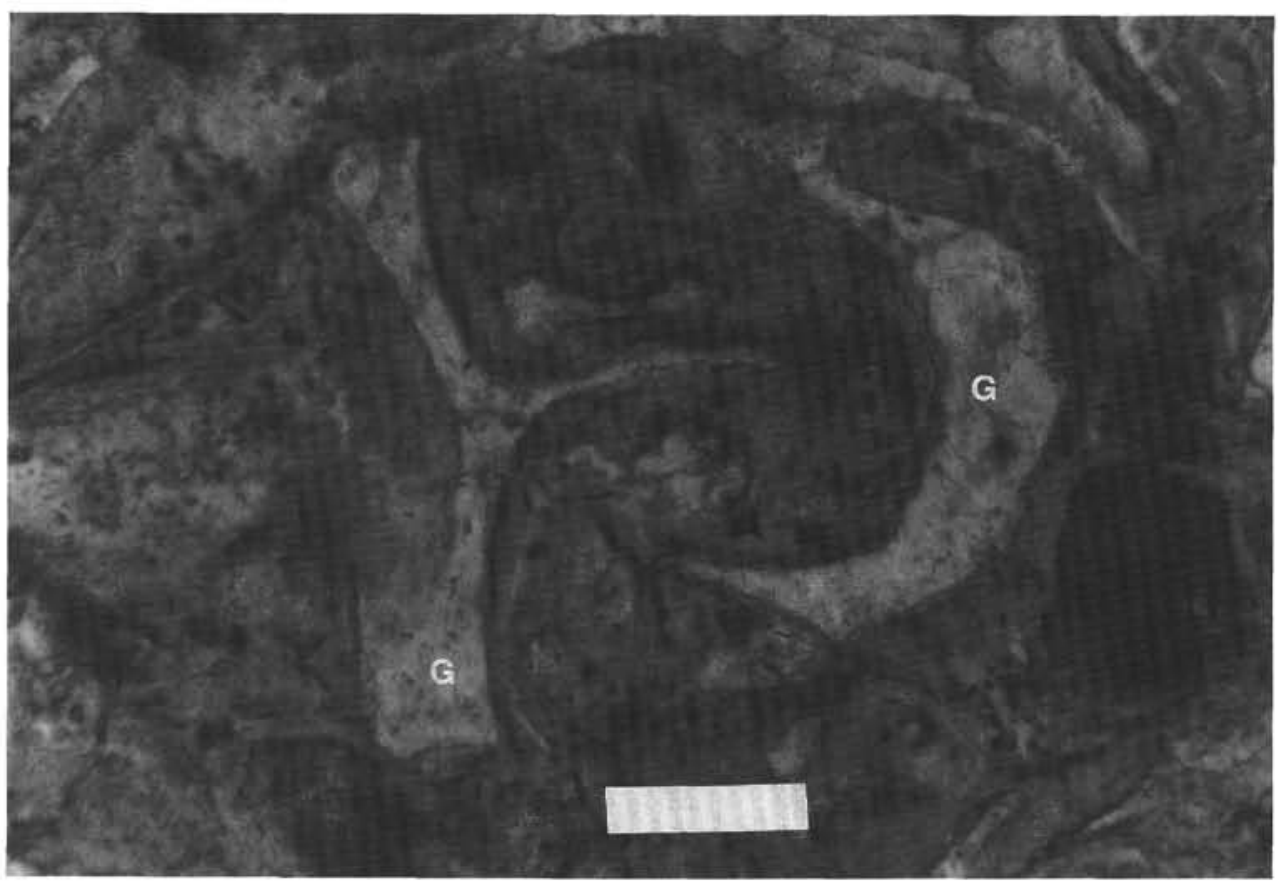

Figure 6. Cuspate and Y-shaped glass shards $(\mathrm{G})$ in a volcaniclastic sandstone. Core 127-796B-18R, approximately 324 mbsf. Plane-polarized light. Scale bar $=0.1 \mathrm{~mm}$.

triangle. Site 796 sandstones plot in a distinctly different part of the lithic arenite (wacke) field, compared to Site 797 sandstones, owing to their markedly lower quartz content. All of the Site 799 sandstones plot within the feldspathic arenite (wacke) field of the classification diagram. Their position within this field reflects their higher content of both quartz and feldspar.

\section{FELDSPAR COMPOSITION}

As mentioned, approximately 650 feldspar grains were analyzed with an electron-probe microanalyzer to determine chemical composition. The results of these analyses are shown in Figures 8-10, which are ternary diagrams that display composition in terms of Or (potassium), Ab (sodium), and An (calcium) end members. The feldspars grains analyzed from Site 796 (Fig. 8) are mainly plagioclase feldspars. They range in composition from anorthite $\left(\mathrm{Or}_{0.4} \mathrm{Ab}_{7.9} \mathrm{An}_{91.7}\right)$ to oligoclase $\left(\mathrm{Or}_{4.7} \mathrm{Ab}_{84.6} \mathrm{An}_{10.7}\right)$. Most of the plagioclase falls within the range of andesine to bytownite; none is albite. Feldspars analyzed from Site 797 (Fig. 9) include both plagioclase and potassium feldspars. A few plagioclase grains from Site 797 are as calcic as andesine $\left(\mathrm{Or}_{0.2} \mathrm{Ab}_{65.2} \mathrm{An}_{34.6}\right)$. Most fall in the albite field, and some are as sodic as $\mathrm{Or}_{0.5} \mathrm{Ab}_{99.5} \mathrm{An}_{0}$. In Figure 9, composition values for more than 100 plagioclase grains overlap in the extreme corner of the albite field. The compositions of many Site 797 plagioclase feldspars have been altered by albitization during diagenesis, as shown by both compositional and petrographic data. Because albitization has modified the original compositions of these feldspars, their chemical compositions cannot be used in provenance analysis. Originally, the composition of many Site 797 plagioclase feldspars was probably much more calcic than that shown in Figure 9. On the other hand, some of the albite in Site 797 sandstones could be detrital. Albites is present in some low-rank metamorphic rocks and can also form by hydrothermal and post-magmatic replacement of feldspars in igneous rocks (AlDahan et al., 1987). Potassium feldspars from Site 797 range in composition from anorthoclase to sanidine. Most fall in the sanidine compositional field, and petrographic analysis shows that most are sanidine rather than orthoclase or microcline. Some K-feldspar grains may have been altered to albite during diagenesis; however, we have no definite petrographic evidence to support albitization of potassium feldspars.

Table 1. Average (mean) percent framework composition of sandstones from Sites 796, 797, and 799.

\begin{tabular}{|c|c|c|c|}
\hline Framework components & Site 796 & Site 797 & Site 799 \\
\hline Monocrystalline quartz & $0.5 \pm 0.6$ & $7.4 \pm 2.4$ & $29.6 \pm 4.4$ \\
\hline Polycrystalline quartz and metaquartzite & $0.2 \pm 0.3$ & $2.3 \pm 1.7$ & $6.7 \pm 1.3$ \\
\hline Chert & $0.3 \pm 0.4$ & $1.6 \pm 1.5$ & $0.4 \pm 0.3$ \\
\hline Sanidine & $0.1 \pm 0.2$ & $6.0 \pm 4.0$ & $0.8 \pm 1.1$ \\
\hline Orthoclase and microcline & 0.0 & $0.3 \pm 0.5$ & $18.2 \pm 5.2$ \\
\hline Plagioclase & $28.0 \pm 17.8$ & $15.5 \pm 9.4$ & $23.0 \pm 4.0$ \\
\hline Volcanic rock fragments and glass & $61.5 \pm 17.9$ & $46.1 \pm 20.5$ & $3.2 \pm 1.8$ \\
\hline Plutonic rock fragments & 0.0 & $0.3 \pm 0.6$ & $6.4 \pm 4.7$ \\
\hline Metamorphic rock fragments & $0.1 \pm 0.2$ & $0.6 \pm 0.7$ & $0.3 \pm 0.5$ \\
\hline Sedimentary rock fragments & 0.0 & $0.5 \pm 0.8$ & $5.3 \pm 3.4$ \\
\hline Indeterminate unstable rock fragments & $0.6 \pm 0.7$ & $4.0 \pm 5.5$ & $1.6 \pm 0.7$ \\
\hline Ripup clasts (intraclasts) & $6.9 \pm 9.1$ & $11.1 \pm 17.8$ & $3.5 \pm 2.8$ \\
\hline Micas & $0.1 \pm 0.2$ & $3.4 \pm 2.3$ & $1.0 \pm 0.9$ \\
\hline Heavy minerals & $1.6 \pm 2.0$ & $1.0 \pm 0.8$ & $0.2 \pm 0.2$ \\
\hline $\mathrm{Q}$ as \% QFR & 1.1 & 13.3 & 38.4 \\
\hline$F$ as \% QFR & 28.6 & 25.9 & 44.0 \\
\hline $\mathrm{R}$ as \% $\mathrm{QFR}$ & 70.3 & 60.8 & 17.6 \\
\hline $\mathrm{R}_{\mathrm{v}}$ as \% total unstable rock fragments & 98.4 & 89.5 & 19.0 \\
\hline $\mathrm{R}_{\mathrm{p}}$ as \% total unstable rock fragments & 0.0 & 0.6 & 38.1 \\
\hline $\mathrm{R}_{\mathrm{m}}^{\mathrm{p}}$ as \% total unstable rock fragments & 0.2 & 1.2 & 1.8 \\
\hline $\mathrm{R}_{\gamma}$ as \% total unstable rock fragments & 0.0 & 1.0 & 31.5 \\
\hline $\mathrm{R}_{\mathrm{i}}$ as \% total unstable rock fragments & 1.4 & 7.8 & 9.5 \\
\hline Plagioclase/total feldspar ratio & 0.99 & 0.71 & 0.55 \\
\hline Total samples & 14 & 43 & 10 \\
\hline
\end{tabular}

$\mathrm{Q}=$ Total quartz + chert + metaquartzite $\mathrm{F}=$ total feldspars; $\mathrm{R}=$ total unstable rock fragments (does not include intraclasts); $R_{v}=$ volcanic rock fragments and glass; $R_{p}$ $=$ plutonic rock fragments; $R_{m}=$ metamorphic rock fragments, excluding metaquartzite; $R_{\mathrm{s}}=$ sedimentary rock fragments, excluding chert; $\mathrm{R}_{\mathrm{i}}=$ indeterminate unstable rock fragments: \pm indicates one standard deviation. 


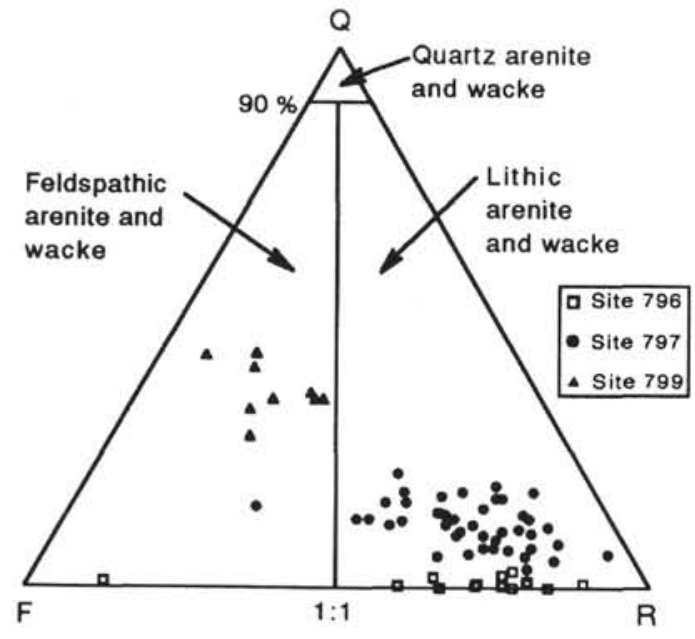

Figure 7. Classification of sandstones from ODP Sites 796, 797, and 799 according to Gilbert (Williams et al., 1982). Q = quartz + chert + metaquartzite clasts; $\mathrm{F}=$ total feldspars; $\mathrm{R}=$ unstable rock fragments, including indeterminate unstable rock fragments, plutonic rock fragments and ripup clasts (intraclasts).

Many of the plagioclase feldspars from Site 799 are albitic (Fig. 10), ranging to $\mathrm{Or}_{0.2} \mathrm{Ab}_{99.7} \mathrm{An}_{0.1}$, although a few are as calcic as andesine $\left(\mathrm{Or}_{1.2} \mathrm{Ab}_{63.8} \mathrm{An}_{35.0}\right)$. The high sodium content of these albites suggests that many Site 799 plagioclase feldspars, like Site 797 feldspars, have also been affected by albitization during diagenesis, although we cannot rule out the possibility that some of the albites are detrital. The alkali feldspars in Site 799 sandstones appear to be largely unaffected by albitization. They range in composition from $\mathrm{Or}_{16.6} \mathrm{Ab}_{78.1} \mathrm{An}_{5.3}$ to $\mathrm{Or}_{98.1} \mathrm{Ab}_{1.9} \mathrm{An}_{0}$, but most fall in the compositional field of sanidine. Petrographic analysis shows that they are mainly orthoclase and microcline.

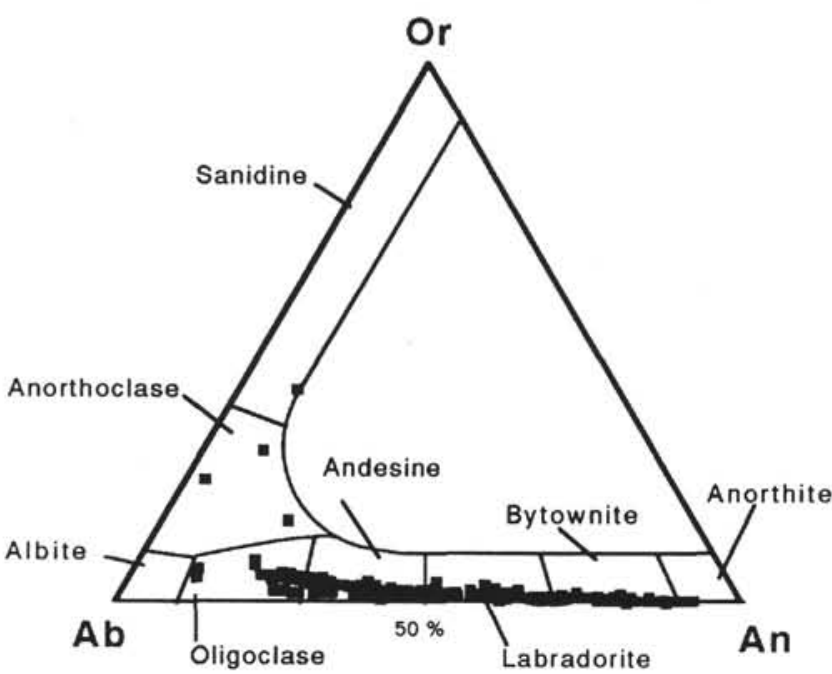

Figure 8. Chemical composition of feldspars from Site 796 displayed on a standard $\mathrm{Or}(\mathrm{K}), \mathrm{Ab}(\mathrm{Na}), \mathrm{An}(\mathrm{Ca})$ diagram. The absence of albitic feldspars suggests that no complete diagenetic albitization of feldspars has occurred in Site 796 sandstones.

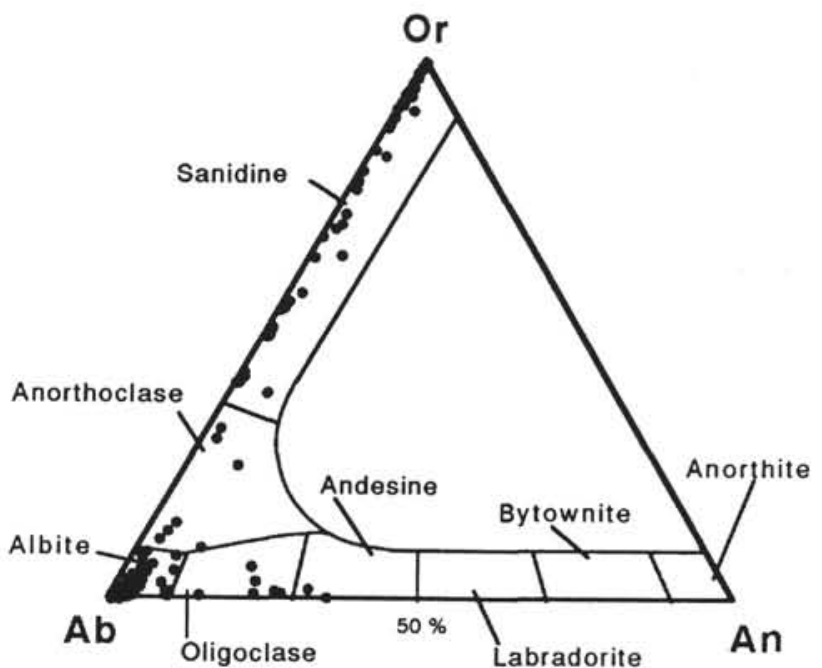

Figure 9. Chemical composition of feldspars from Site 797. The high concentration of feldspar in the albite composition field suggests extensive diagenetic albitization of Site 797 plagioclase feldspars.

\section{PROVENANCE INTERPRETATION}

\section{Source-Rock Lithology}

The lithology of the source areas that furnished detritus to Sites 796, 797, and 799 can be interpreted from the detrital framework mineralogy shown in the Appendix and Table 1. The overwhelming dominance of volcanic rock fragments, glass, and plagioclase feldspars in Site 796 sandstones indicates that these sandstones were derived almost entirely from volcanic source rocks. The chemical compositions of the plagioclase feldspars (Fig. 8), which have not

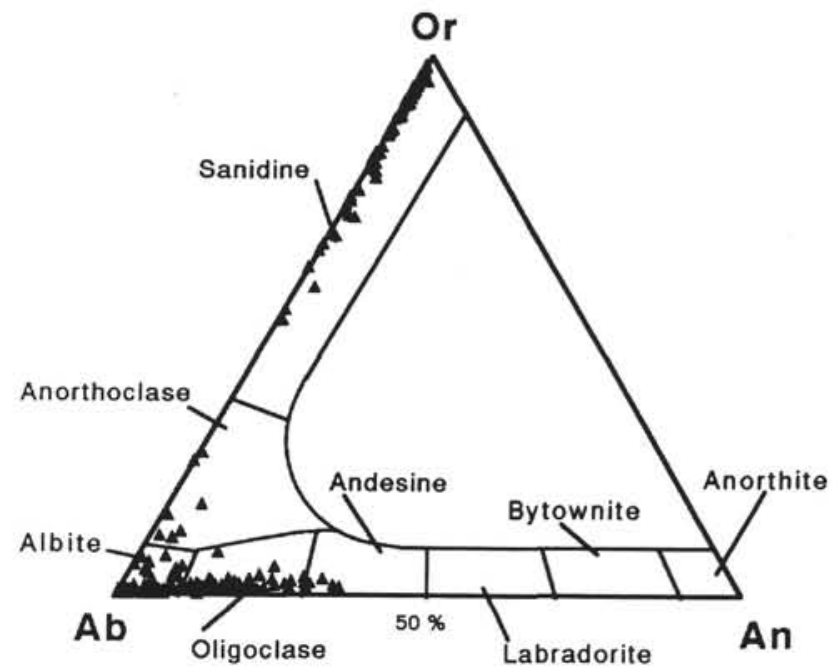

Figure 10. Chemical composition of feldspars from Site 799 sandstones. Most of the plagioclase feldspars are very sodium rich, suggesting diagenetic albitization. The potassium feldspars show no evidence of sodium enrichment. 


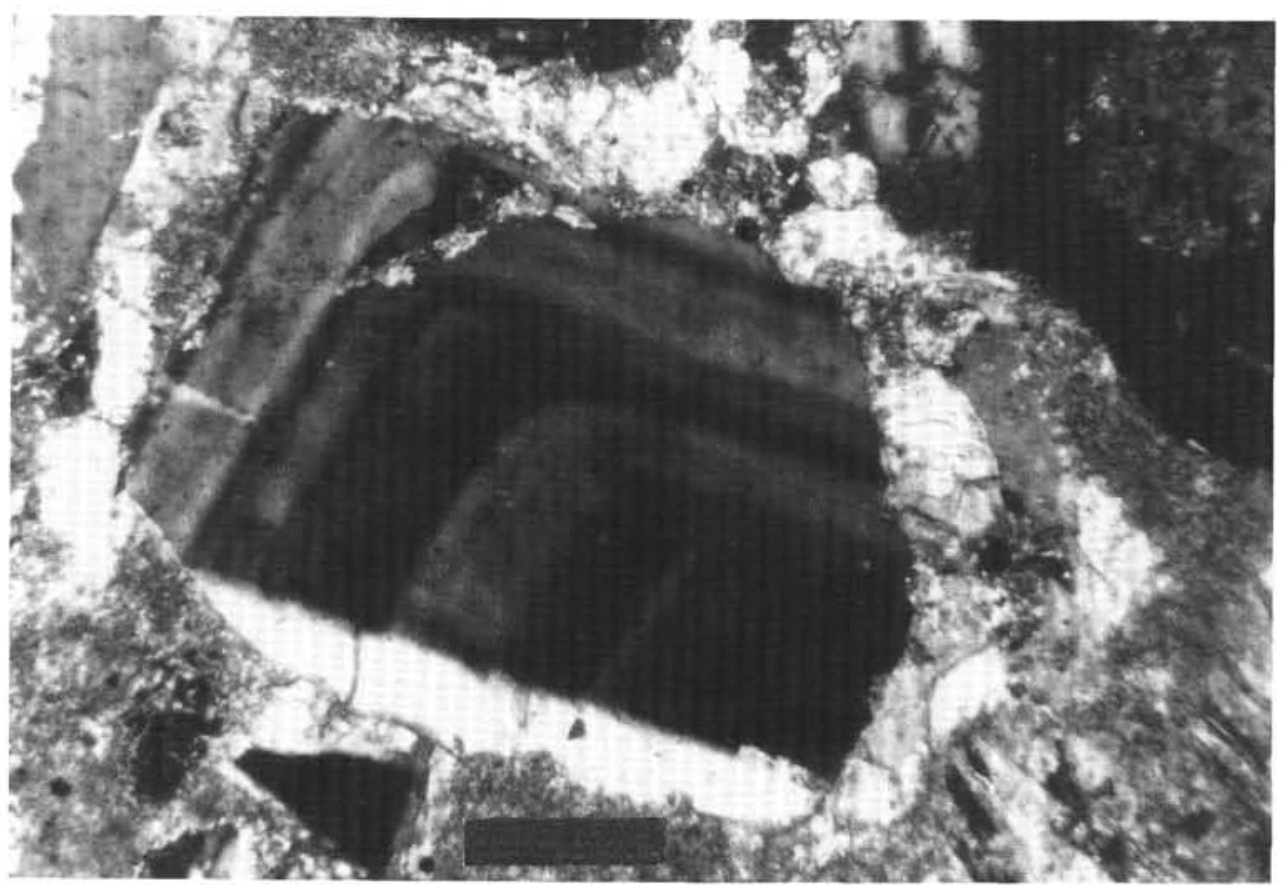

Figure 11. Broken, oscillatory zoned plagioclase, Core 127-796B-11R, approximately $253 \mathrm{mbsf}$. Crossed nicols. Scale bar $=0.1 \mathrm{~mm}$.

been affected by albitization, also are consistent with a volcanic source. The compositions of many of the plagioclase grains fall within the oligoclase to andesine compositional fields. Plagioclase more sodic than $\mathrm{Ab}_{50}$ is not common in plutonic and metamorphic rocks (Trevena and Nash, 1981). The more calcic volcanic plagioclases have compositions that overlap the compositional fields of plutonic and metamorphic rocks. The plagioclase compositions suggest that the volcanic source rocks ranged in composition from andesites to basalts. The volcanic rock fragments, glass, and feldspar grains in Site 796 sands are dominantly subangular to angular, which indicates that they did not undergo extensive abrasive transport on land. Furthermore, many of the rock fragments and feldspars are fresh and unaltered, suggesting that they were not subjected to prolonged subaerial weathering. Most of the glass shards have been diagenetically altered to zeolites, but many still retain recognizable shapes (Fig. 6). Many of the feldspar grain are broken, and some show oscillatory zoning (Fig. 11), which is typical of volcanic feldspars. The abundance of glass in Site 796 sandstones, together with other characteristics of the framework grains discussed above, suggest that the source rocks were pyroclastic deposits. The extremely low quartz and metamorphic and sedimentary rock fragment content further indicates that epiclastic processes (weathering of older source rocks) probably played a minor role in furnishing sediment to Site 796. We are not certain whether the pyroclastic source materials were erupted on land or subaqueously within the Japan Sea. In either case, they must have been remobilized and retransported by sediment gravity flows to Site 796 .

Sandstones from Site 797 also contain a predominance of volcanic rock fragments, glass, and plagioclase feldspars. The common presence of broken plagioclase grains, bubble-wall glass shards, moderately abundant angular sanidine grains, and angular volcanic rock fragments suggest that the framework grains were derived in part from a pyroclastic volcanic source. Weathering of older lava flows may also have furnished some clasts and feldspars. On the other hand, Site 797 sandstones contain higher percentages of quartz, metamorphic rock fragments, chert and other sedimentary rock fragments than do Site 796 sandstones. They also contain minor amounts of ortho- clase, microcline, biotite, muscovite, detrital chlorite, metamorphic heavy minerals (sillimanite and andalusite), and very minor amounts of plutonic rock fragments. Thus, at least a small component of the framework constituents in Site 797 sandstones was derived from metamorphic and sedimentary rocks and possibly plutonic rocks.

Other evidence also supports an interpretation of an epiclastic source for some of the framework grains in Site 797 sandstones. For example, many of the quartz grains in Site 797 sandstones contain inclusions of rutile, apatite, or tourmaline (Fig. 12). By contrast, volcanic quartz is commonly clear and inclusion-free. Also, some of the quartz grains are polycrystalline grains that contain more than three crystal units per grain (Fig. 13), and many of the monocrystalline quartz grains display undulatory extinction. Basu et al. (1975) demonstrated that polycrystallinity and undulatory-extinction in firstcycle quartz grains can be of value in interpreting the provenance of quartz. Figure 14 shows polycrystallinity and undulatory extinction data for Site 797 quartz grains plotted on the quartz-provenance diagram of Basu et al (1975). This diagram shows that the quartz was likely derived from middle- and upper-rank metamorphic and plutonic rocks. This technique may not be adequate to differentiate between volcanic and plutonic quartz, but it does suggest that both igneous and metamorphic quartz are present.

Pittman (1970) has shown that the composition, zoning, and twinning characteristics of feldspars have value in interpreting provenance. Site 797 plagioclase feldspars show evidence on the basis of both chemical composition and petrographic characteristics that they have undergone significant albitization during diagenesis (see Boggs and Seyedolali, this volume). For example, a significant proportion of Site 797 plagioclase grains are untwinned, which may reflect loss of twins by albitization (e.g., Morad et al., 1990). Most of the plagioclase grains are albitized. Thus, much of the provenance information that might have been gained from the chemical composition of Site 797 plagioclase feldspars has been lost owing to diagenesis. On the other hand, the potassium feldspars appear to be little altered by albitization. Some of these feldspars have very high potassium 


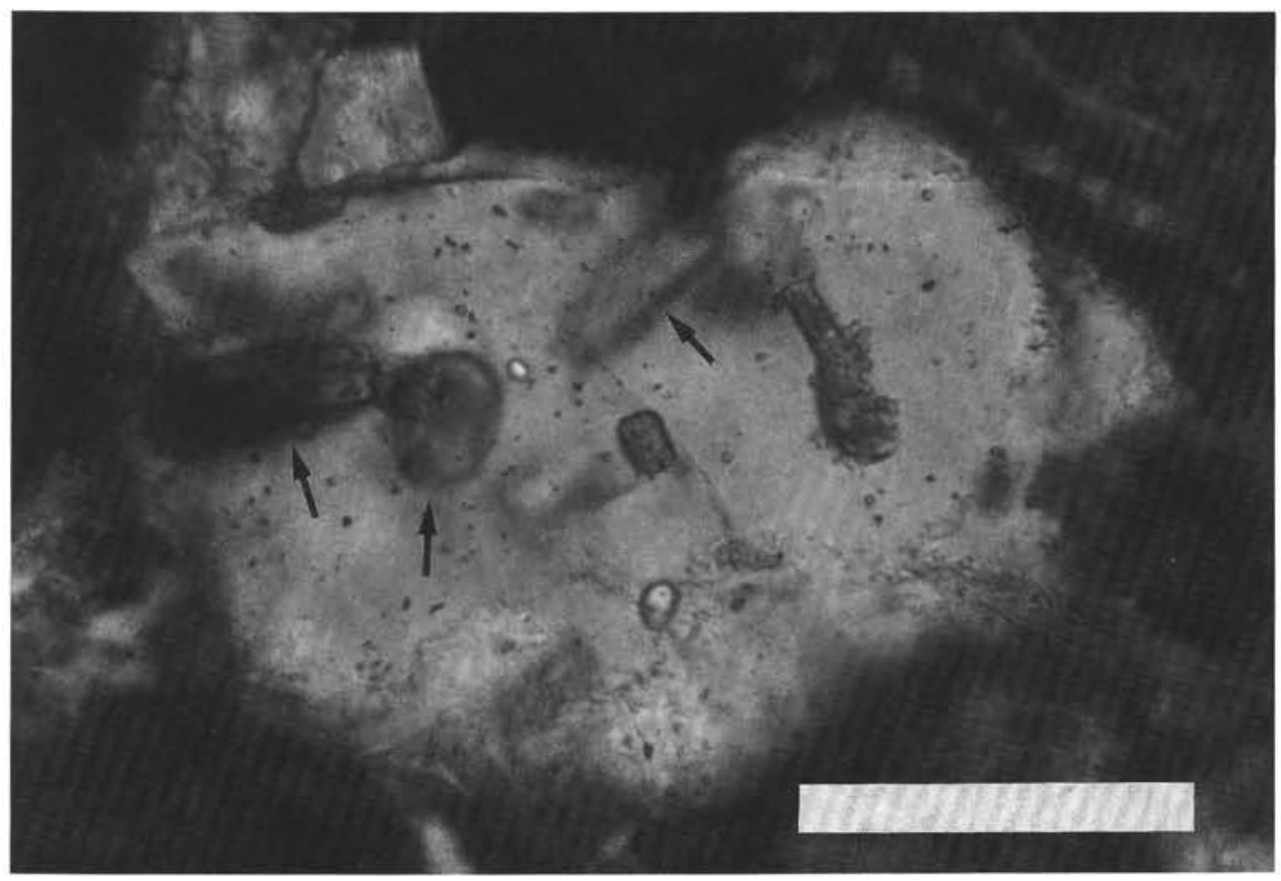

Figure 12. Monocrystalline quartz with inclusions of tourmaline (arrows), Core 127-797C-37R, approximately 822 mbsf. Scale bar $=0.1 \mathrm{~mm}$.

content $\left(>\mathrm{Or}_{90}\right)$, as shown in Figure 9. Trevena and Nash (1981) report that detrital alkali feldspars more potassic than $\mathrm{Or}_{87}$ are likely derived from metamorphic or plutonic sources.

The framework composition of Site 799 sandstones indicates that these sandstones were derived from source rocks very different in composition from the source rocks for Sites 796 and 797 sandstones. Volcanic rock fragments and glass make up only a minor fraction of the framework grains compared to Site 796 and 797 sandstones. The high quartz $(\sim 36 \%)$, orthoclase and microcline $(\sim 18 \%)$, and granite rock-fragment $(\sim 6 \%)$ content of Site 799 sandstones indicates derivation of much of Site 799 sediment from granitic plutonic rocks. The moderate content of sedimentary rock fragments $(\sim 5 \%)$ suggests that sedimentary rocks must also have been present in the source area. The high average abundance of quartz in Site 799 samples makes it highly unlikely that the quartz was derived mainly from volcanic sources. Much of it was probably derived from plutonic (granitic) rocks, although some may have come from metamorphic or sedimentary sources. Site 799 samples were not received in time to obtain data on

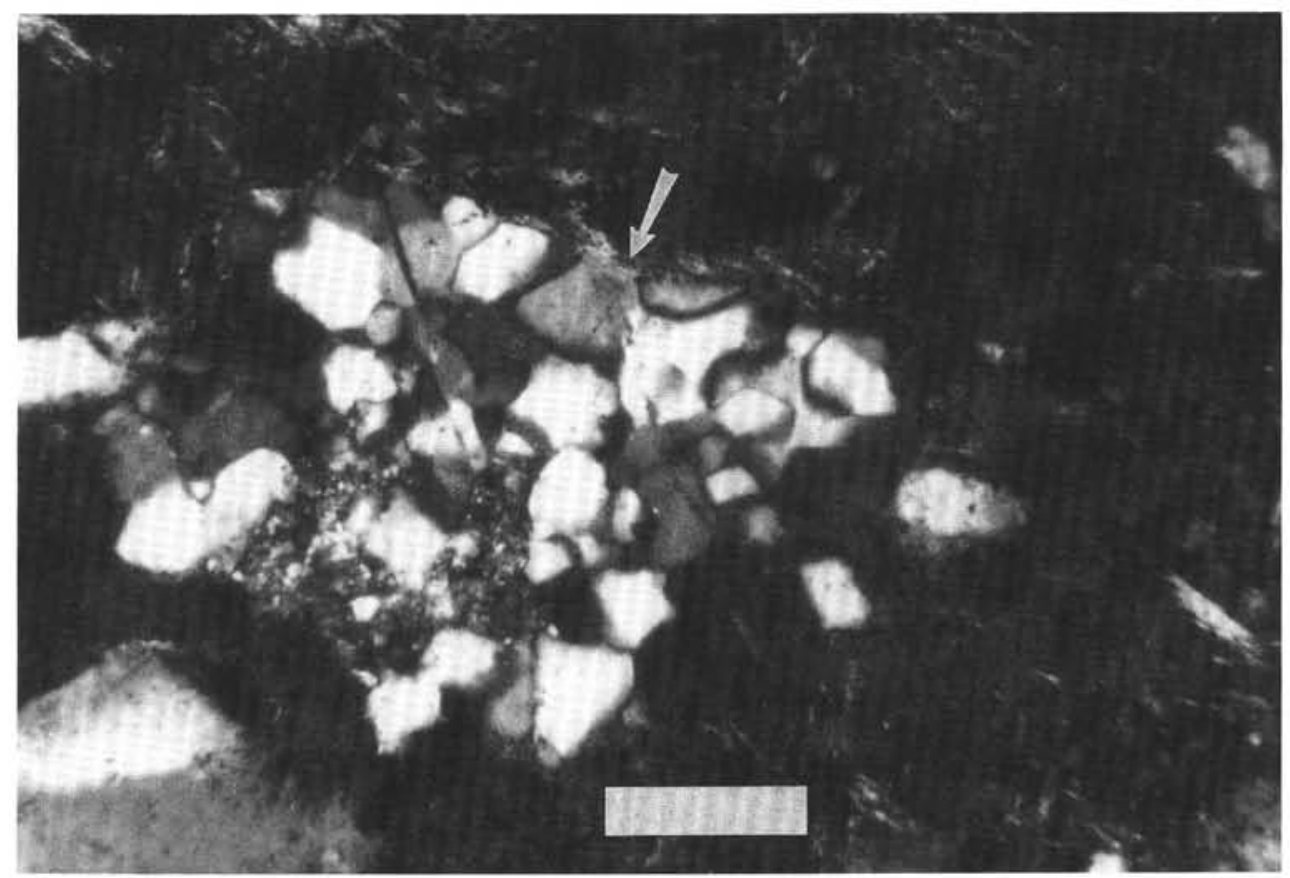

Figure 13. Polycrystyalline quartz grain (arrow) in volcaniclastic sandstone. Core 127-797C-37R, approximately 818 mbsf. Crossed nicols. Scale bar $=0.1 \mathrm{~mm}$. 


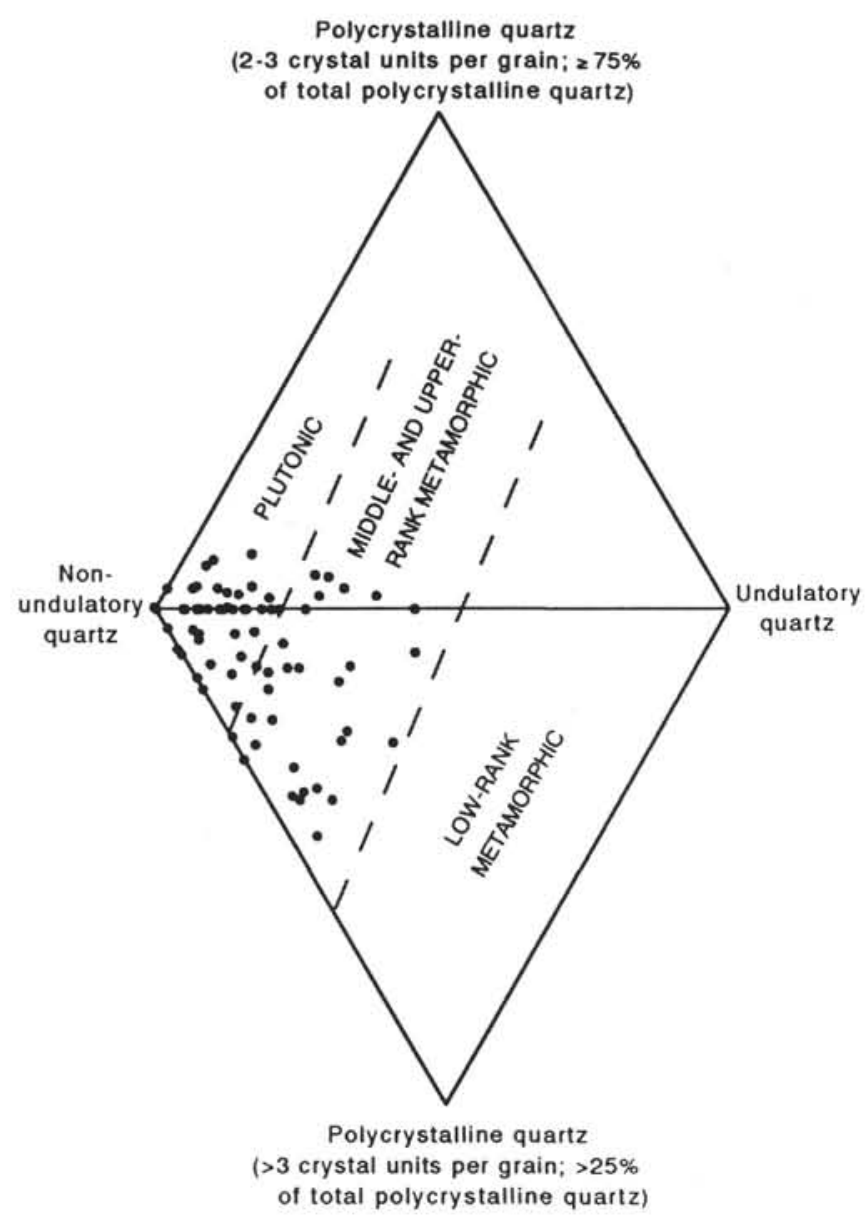

Figure 14. Measured values of undulatory extinction and polycrystallinity for Site 797 quartz grains plotted on the provenance diagram of Basu et al. (1975).

polycrystallinity and undulose extinction of the quartz grains, which might have been used to differentiate between metamorphic and plutonic sources.

Because the plagioclase feldspars in Site 799 sandstones were probably albitized during diagenesis, plagioclase composition is not a reliable indicator of source-rock composition. By contrast, the potassium feldspars appear to be unaffected by albitization. The compositions shown in Figure 10 and the high abundance of orthoclase (and minor microcline) feldspars (Table 1), many of which display coarse, perthitic lamellae, indicate derivation from felsic plutonic sources.

In summary, the detrital components of Site 796 sandstones were derived primarily from volcanic, likely pyroclastic, source rocks. Site 797 sandstones were likewise derived mainly from volcanic source rocks, which may have included both pyroclastic deposits and lava flows, but a small component of Site 797 sediment came from metamorphic and possibly sedimentary and plutonic rocks. Site 799 sandstones had only a minor volcanic source. Instead, the detritus in these sandstones was derived primarily from plutonic (granitic) rocks and to a lesser extent from sedimentary and possibly metamorphic rocks.

\section{Tectonic Provenance}

To fully evaluate the provenance of Site 796, 797, and 799 sandstones, we have looked not only at the lithology of source rocks but also at the tectonic setting of the source areas. Dickinson and Suzcek (1979), Dickinson et al. (1983), and Dickinson (1985) suggest that sediments may be derived from three kinds of tectonic settings

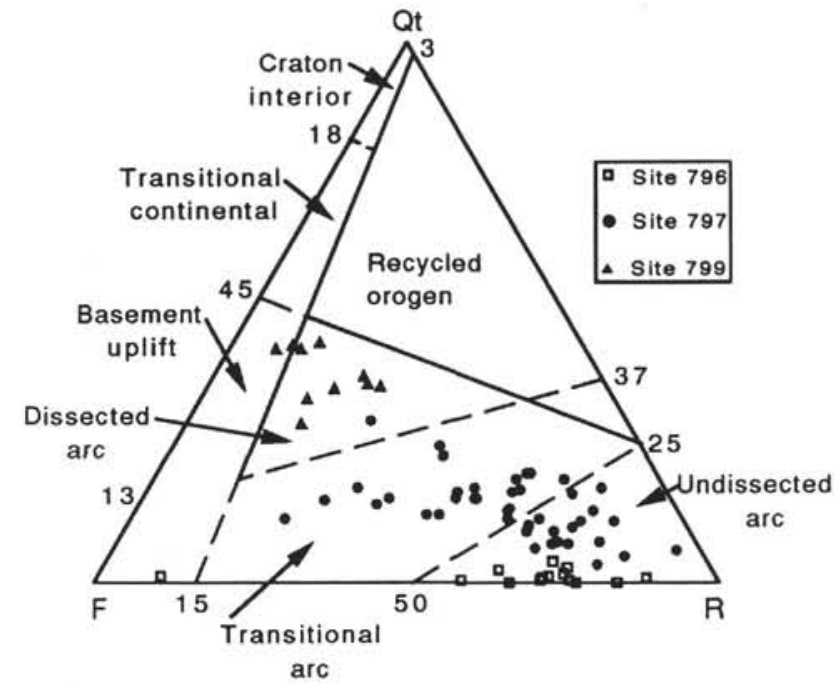

Figure 15. Tectonic provenance of sandstones from Sites 796, 797, and 799 as interpreted from QtFR framework constituents. Qt $=$ total quartzose grains (quartz, chert, metaquartzite grains), $\mathrm{F}=$ total feldspars, $\mathrm{R}=$ unstable rock fragments excluding ripup clasts (intraclasts).

or tectonic provenances: continental blocks, recycled orogens, and magmatic arcs. Continental blocks include major shields and platforms and locally upfaulted basement blocks. Recycled orogens are source regions created by upfolding or upfaulting of sedimentary or metasedimentary rocks, which allows detritus from these rocks to be recycled to associated basins. Magmatic arcs consist of modern or ancient volcanic highlands located along active island arcs or on continental margins. Magmatic arcs may be divided into: (1) undissected arcs, which have a nearly continuous cover of volcanic rocks, (2) dissected arcs, which have been deeply eroded to expose plutonic and possibly metamorphic and sedimentary rocks, and (3) transitional arcs, which have undergone less erosion than dissected arcs.

Dickinson and Suzcek (1979) proposed that detrital sandstone modes (percentages of quartz, feldspar, lithic fragments) can be used to interpret tectonic setting. On the basis of petrographic data obtained from locally derived sands of known provenance, they constructed provenance diagrams that show the relationship between sandstone detrital modes and tectonic setting. These provenance diagrams were subsequently refined into more general provenance models by Dickinson et al. (1983). Figures 15 and 16 show petrographic data from Site 796, 797, and 799 sandstones plotted on Dickinson et al's. (1983) diagrams. Framework compositional data from the Appendix are recomputed and plotted in Figure 15 as total quartzose grains $(\mathrm{Qt})$, total feldspars $(\mathrm{F})$, and unstable rock fragments (R), including plutonic rock fragments. (The symbol $\mathrm{R}$, instead of $\mathrm{L}$, is used for unstable rock fragments, following Ingersoll et al. (1984), who suggest that $R$ be used for point-count data obtained by the traditional point-counting method.) Unstable rock fragments are defined as all rock fragments except chert and metaquartzite clasts. Ripup clasts (intraclasts) are included with rock fragments (R) in Figure 7 for classification purposes; however, they are not included with rock fragments in Figures 15 and 16 because intrabasinal grains do not have provenance significance. Total quartzose grains includes monocrystalline quartz, polycrystalline quartz (including metaquartzite clasts), and chert. The end members in Figure 16 are monocrystalline quartz $(\mathrm{Qm})$, total feldspars (F), and total rock fragments (Rt), which include polycrystalline quartz, chert, and metaquartzite.

Figures 15 and 16 show fairly distinct separation of sandstones from the three sites within the provenance fields. Sandstones from Site 796 plot mainly within the undissected-arc field and very near the base of the provenance diagrams, which shows that they contain 


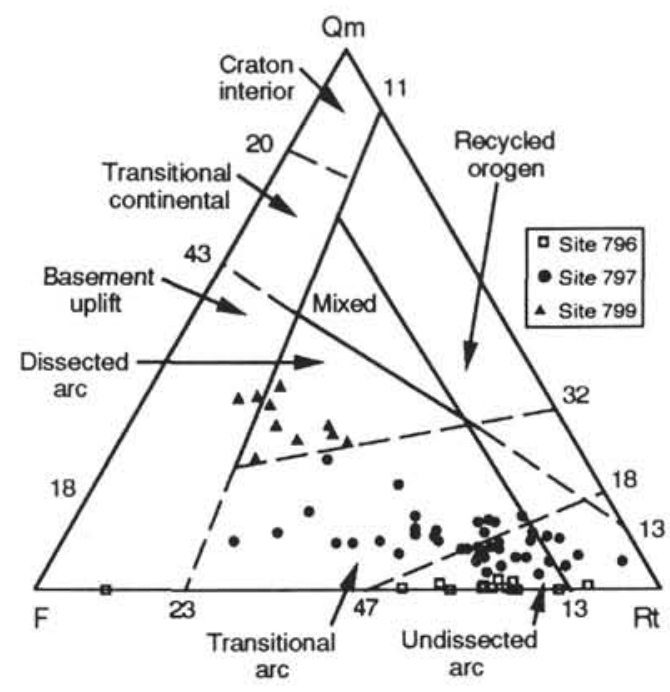

Figure 16. Tectonic provenance of sandstones from Sites 796, 797, and 799 as interpreted from QmFRt framework constituents. $\mathrm{Qm}=$ monocrystalline quartz, $\mathrm{F}=$ total feldspars, $\mathrm{Rt}=$ total lithic grains including polycrystalline quartz, chert, and metaquartzite fragments, but excluding ripup clasts (intraclasts).

very little quartz. Site 797 sandstones plot mainly within the undissected-and transitional-arc fields, although a few samples fall within the recycled-orogen field. Site 799 sandstones plot mainly in the dissected-arc and basement-uplift fields. (As mentioned, the petrographic data upon which these plots are based were obtained by using the traditional point-counting method. Had we used the GazziDickinson point-counting method, some shift in the points away from the rock-fragment pole would likely have occurred. For example, more of the Site 799 sample points would probably fall in the basement-uplift field.) The detrital sandstone modes thus indicate distinctly different tectonic provenances for the sandstones from the three sites. Site 796 sandstones were derived from a magmatic-arc tectonic setting that consisted almost entirely of volcanic rocks. Site 797 sandstones were derived from a magmatic arc that was partially dissected to expose some plutonic, metamorphic, and sedimentary rocks. The tectonic setting of Site 799 source rocks was clearly different from that of Site 796 and 797 sandstones. The setting was probably a highly eroded (dissected) magmatic arc in which plutonic (granitic), metamorphic, and sedimentary rocks were exposed, and in which only remnants of the volcanic cover remained. The source area may have included uplifted granitic basement blocks (continental blocks).

\section{Location of Source Areas}

\section{Site 796}

Reference to Figure 1 shows that Site 796 is located in the northeastern end of the Japan Basin near the southwestern tip of Hokkaido. Although the Japan Basin may have been somewhat narrower in late Miocene to Pliocene time than it is today (Iijima and Tada, 1990), Site 796 was probably located quite close to Hokkaido at that time. The petrologic characteristics of Site 796 sandstones described above indicate that they are fresh, first-cycle deposits and that they were derived mainly from pyroclastic source rocks. Some of the pyroclastic source deposits were probably erupted subaerially on Hokkaido; others may have erupted subaqueously within the Japan Sea. In either case, they were retransported by sediment-gravity-flow processes fairly soon after eruption. Absence of significant weathering alteration of feldspars and volcanic rock fragments indicates that the pyroclastic detritus could not have undergone extensive weathering.

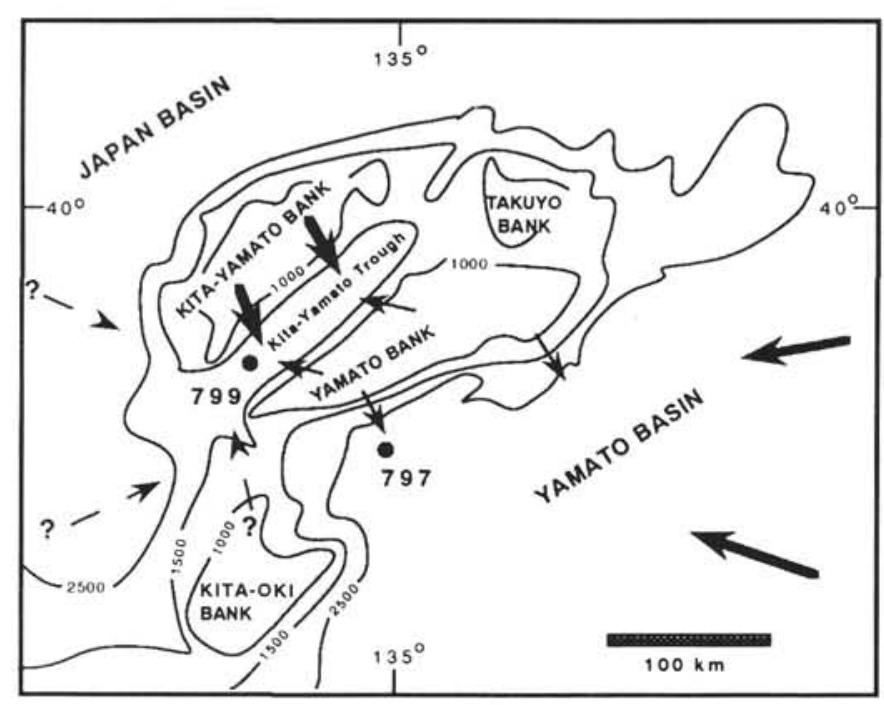

Figure 17. Bathymetric map of Yamato Rise (see Fig. 1) and adjacent areas showing the locations of Sites 797 and 799 . The arrows show the inferred general direction of sediment transport from the source areas. The heavier arrows indicate the most important sources. Bathymetric contours generalized from Tamaki (1988).

\section{Site 797}

This site is located in Yamato Basin between Yamato Rise and Honshu, Japan (Fig. 1). The site is southeast of the southwest end of Yamato Bank, which is the easternmost bank on Yamato Rise (Fig. 17). Although the present water depth at Site 797 is $2865 \mathrm{~m}$, the water depth in early Miocene time when Site 797 sandstones were deposited was likely shallower. The site was probably situated on a submarine slope at upper-bathyal water depths (Shipboard Scientific Party, 1990d). The Japan Sea was narrower at that time than it now is, because the rifting that formed the Japan Sea began in middle early Miocene time (Shipboard Scientific Party, 1990a). Therefore, Site 797 was probably located much closer in early Miocene time to both the Asian mainland and Japan than it is today. Thus, both Japan and Asia are potential source areas for Site 797 sands. Another possible source area is Yamato Bank (Fig. 17) on Yamato Rise. The shallowest part of Yamato Rise is now submerged about $500 \mathrm{~m}$ below sea level; however, wave-cut terraces on the top of the Rise indicate that the top was once near sea level (Tamaki, 1988). Yamato Bank is composed mainly of volcanic rocks. These volcanic rocks are andesites and basalts, which have been radiometically dated to have ages ranging from Eocene to Oligocene (46-20 Ma) (Tamaki, 1988). If Yamato Bank was at or above sea level in early Miocene time (see discussion below), it could have furnished some volcaniclastic detritus to Site 797. On the other hand, the presence of this bank, and the ridge connecting Yamato Bank and Kita-Oki Bank (Fig. 17), may have prevented sediment from the Asian side of the Japan Basin from reaching Site 797.

\section{Site 799}

Site 799 is located in the southwestern end of Kita-Yamato Trough, which lies between Yamato Bank and Kita-Yamato Bank, the westernmost bank of Yamato Rise (Fig. 17). Present water depth at this site is $2072 \mathrm{~m}$. Water depth in early Miocene time when Site 799 sands were deposited may have been slightly shallower. Site 799 sandstones are interbedded with claystones containing deep-water benthic foraminifers that indicate a water depth of 1500-2000 m (Shipboard Scientific Party, 1990c). As discussed above, Site 799 sandstones have only a weak volcanic provenance signature, and must have been 
derived primarily from granitic plutonic rocks with some associated metamorphic and sedimentary rocks. The source area for Site 799 sandstones was clearly different from that for Site 797 sandstone. It probably lay to the west of Site 799 , where abundant granitic rocks are present, rather than to the east toward Japan. The closest source of granites to Site 799 is nearby Kita-Yamato Bank (Fig. 17). KitaYamato Bank is composed mainly of granites and granodiorites that range in age from Jurassic to Early Cretaceous (197-110 Ma) (Tamaki, 1988). Seismic data indicate that well stratified sedimentary rocks (age ?) directly overlie the basement rocks. We suggest that Kita-Yamato Bank is the most likely source of the granitic and possibly sedimentary detritus in Site 799 sandstones. This interpretation requires that Kita-Yamato Bank must have stood at or above sea level in early Miocene time. Granitic rocks are also present in the northern part of Kita-Oki Bank (Tamaki, 1988), which may have furnished some granitic detritus to Site 799. The fact that very little granitic detritus reached Site 797 suggests that Yamato Bank, and the ridge connecting Yamato Bank and Kita-Oki Bank (Fig. 17), lay between Site 797 and Site 799, and thus acted as a barrier to sediment transport from the west. Likewise, Yamato Bank may have prevented turbidity currents from the Japan side of the Yamato Basin from reaching Site 799, which could account for the low content of volcanic rock fragments and glass in Site 799 sandstones.

If Kita-Yamato bank was the main source of granitic detritus for Site 799 sandstones, the bank must have subsided somewhat by Pliocene time. Pliocene sediments are now present around the margins of the bank (Tamaki, 1988).

A possible additional source of granitic detritus and metamorphic and sedimentary rock fragments for Site 799 sandstones is the Asian mainland. Granitic, metamorphic, and sedimentary source rocks are all present along the eastern margin of Korea. Granitic rocks ranging in age from 171 to 74 Ma crop out over large areas of Korea (Reedman and Um, 1975). Also, sedimentary, metamorphic, and volcanic rocks that range in age variously from Precambrian to Cretaceous are present within Korea (Reedman and Um, 1975; Sillitoe, 1977). Granitic rocks are also present on the Korea Plateau in the southern part of the Japan Basin (Tamaki, 1988). We consider Korea to be a less likely site for the source rocks of Site 799 sandstones than Yamato Rise for two reasons. First, Kita-Yamato Bank was probably much closer to Site 799 in early Miocene time than was Korea. Secondly, sedimentary and metamorphic rocks make up a much greater volume of the potential source rocks in Korea than do granitic rocks. A greater proportion of sedimentary and metamorphic detritus, compared to granitic detritus, should be present in Site 799 sandstones if they were derived primarily from Korea.

\section{DISCUSSION AND CONCLUSIONS}

Sandstone detrital modes and feldspar compositions indicate that the sandstones recovered during ODP drilling at Sites 796, 797, and 799 in the Japan Sea were derived from different kinds of source rocks and that the source areas were widely separated. Miocene sandstones from Site 796, in the northeastern part of the Japan Basin, were derived from dominantly pyroclastic volcanic sources that lay in an undissected magmatic arc on or near southwestern Hokkaido, Japan. The source rocks for Site 797 sandstones, located in the Yamato Basin southeast of Yamato Rise, are also largely volcanic rocks. A small component of epiclastic, nonvolcanic detritus in these sands indicates that the source area for Site 797 sandstones lay in an undissected to dissected magmatic arc, which included some metamorphic, sedimentary, and plutonic rocks. This source area was probably located in west-central Honshu, Japan. The average QFR percentages for Site 797 sandstones $(\sim 13 \%, 26 \%, 61 \%)$ are remarkably similar to the values reported by Packer and Ingersoll (1986) for DSDP Site 299 Quaternary sediments $(13 \%, 24 \%, 63 \%)$. The similarities in composition of sandstones at these two sites, both of which are in the Yamato
Basin, suggests that the source rocks for this basin may not have changed greatly between Miocene and Quaternary time.

The detrital constituents in sandstones from Site 799, located in the southern end of Kita-Yamato Trough on Yamato Rise, were shed from a source area or areas that was distinctly different from those that furnished sediment to Sites 796 and 797. Site 799 source rocks were largely granitic rocks, although they included some sedimentary and metamorphic rock. The most likely source area for these sandstones is Kita-Yamato Bank on Yamato Rise, which consists largely of granites ranging in age from Jurassic to Early Cretaceous. A secondary source for Site 799 sandstones may have been Korea. The average QFL composition of Site 799 sandstones ( 38\%, 44.0\%, $18 \%)$ is closer to that of Quaternary sands at DSDP Site $301(24 \%$, $53 \%, 23 \%$ ) in the Japan Basin (Fig. 1), reported by Packer and Ingersoll (1986), than to that of the Miocene sandstones at Site 797. Although this similarity suggests similar sources, the much higher content of volcanic rock fragments and the lower quartz content of Site 301 sandstones compared to Site 799 sandstones indicates a more important volcanic source for Site 301 sandstones. Packer and Ingersoll suggest that the Quaternary sands at Site 301 were derived both from the Asian mainland and the Honshu arc.

All of the sandstones at Sites 796, 797, and 799 appear to be the deposits of sediment gravity flows, which were probably turbidity currents. They were deposited at water depths ranging from upper bathyal ( $500 \mathrm{~m}$ ?) to perhaps $2000 \mathrm{~m}$. The early Miocene sandstones at Sites 797 and 799 were deposited shortly after initial rifting of the Japan Sea, which began in middle early Miocene time. At that time, the Japan Sea was much narrower than at present, and Sites 797 and 799 lay closer to both the Asian mainland and Japan than they do today.

\section{ACKNOWLEDGMENTS}

We wish to thank the Ocean Drilling Program, Texas A\&M University, for furnishing the samples for this study. Funds for the research were provided by the National Science Foundation (Grant No. EAR 8903497) through the Ocean Drilling Program. Michael Schaffer and Roy Torley, Department of Geological Sciences, University of Oregon, provided technical assistance with electron-microprobe analyses and data reduction. Editorial comments by Raymond V. Ingersoll were greatly appreciated.

\section{REFERENCES}

AlDahan, A. A., Morad, S., and Collini, B., 1987. Clouded-untwinned albite in the Siljan Granite, central Sweden. Neues. Jahrb. Mineral. Monatsch., 1987:327-335.

Basu, A., Young, S. W., Suttner, L. J., James, W. C., and Mack, G. H., 1975. Re-evaluation of the use of undulatory extinction and polycrystallinity in detrital quartz for provenance interpretation. J. Sediment. Petrol., 45:873-882.

Boggs, S., 1984. Quaternary sedimentation in the Japan arc-trench system. Geol. Soc. Am. Bull., 95:669-685.

Dickinson, W. R., 1985. Interpreting provenance relations from detrital modes of sandstones. In Zuffa, G. G.(Ed.), Provenance of Arenites: Dordrecht (D. Reidel), 333-361.

Dickinson, W. R., Beard, L. S., Brakenridge, G. R., Erjavec, J. L., Ferguson, R. C., Inman, K. F., Knepp, R. A., Lindberg, F. A., and Ryberg, P. T., 1983. Provenance of North American Phanerozoic sandstones in relation to tectonic setting. Geol. Soc. Am. Bull., 94:222-235.

Dickinson, W. R., and Suczek, C. A., 1979. Plate tectonics and sandstone composition. AAPG Bull., 63:2164-2182.

Houghton, H. F., 1980. Refined techniques for staining plagioclase and alkali feldspars in thin section. J. Sediment. Petrol., 50:629-631.

lijima, A., and Tada, R., 1990. Evolution of Tertiary sedimentary basins of Japan in reference to opening of the Japan Sea. J. Fac. Sci., Univ. Tokyo, 22:121-171.

Ingersoll, R. V., Bullard, T. F., Ford, R. L., Grimm, J. P., Pickle, J. D., and Sares, S. W., 1984. The effect of grain size on the detrital modes: a test of the Gazzi-Dickinson point-counting method. J. Sediment. Petrol., 54:103-116. 
Morad, S., Bergan, M., Knarud, R., and Nystuen, J. P., 1990. Albitization of detrital plagioclase in Triassic reservoir sandstones from the Snorre Field, Norwegian North Sea. J. Sediment. Petrol., 60:411-425.

Packer, B. M., and Ingersoll, R. V., 1986. Provenance and petrology of Deep Sea Drilling Project sands and sandstones from the Japan and Mariana forearc and backarc regions. Sed. Geol., 51:5-28.

Pittman, E. D., 1970. Plagioclase feldspars as an indicator of provenance in sedimentary rocks. J. Sediment. Petrol., 40:591-598.

Reedman, A. J., and Um, S. H., 1975. The Geology of Korea. Geol. Mineral Inst. Korea, 79-94.

Shipboard Scientific Party, 1990a. Background, objectives, and principal results, ODP Leg 127, Japan Sea. In Tamaki, K., Pisciotto, K.., and Allan, J., et al., Proc. ODP, Init. Repts., 127: College Station, TX (Ocean Drilling Program), 5-33.

1990b. Introduction, background, and principal results of Leg 128 of the Ocean Drilling Program, Japan Sea. In Ingle, J. C., Jr., Suyehiro, K., and von Breymann, M., et al., Proc. ODP, Init. Repts., 128: College Station, TX (Ocean Drilling Program), 5-38.

,1990c. Site 797. In Tamaki, K., Pisciotto, K., Allan, J., et al., Proc. ODP, Init. Repts., 127: College Station, TX (Ocean Drilling Program), 323-421.

, 1990d. Site 799. In Ingle, J. C., Jr., Suyehiro, K., and von Breymann, M. T., et al., Proc. ODP, Init. Repts., 128: College Station, TX (Ocean Drilling Program), 237-402.
Sibley, D. F., and Pentony, K. J., 1978. Provenance variation in turbidite sediments, Sea of Japan. J. Sediment. Petrol., 48:1241-1248.

Sillitoe, R. H., 1977. Metallogeny of an Andean-type continental margin in South Korea: implications for opening of the Japan Sea. In Talwani, M., and Pitmann, W. C., III (Eds.), Island Arcs, Deep Sea Trenches and Back-arc Basins. Am. Geophys. Union, 303-310.

Suttner, L. J., and Basu, A., 1985. The effect of grain size on detrital modes: a test of the Gazzi-Dickinson point-counting method-Discussion. J. Sediment. Petrol., 55:616-617.

Tamaki, K., 1988. Geological structure of the Japan Sea and its tectonic implications. Bull. Geol. Survey Jpn., 39:269-365.

Trevena, A. S., and Nash, W. P., 1981. An electron microprobe study of detrital feldspars. J. Sediment. Petrol., 51:137-150.

Williams, H., Turner, F. J., and Gilbert, C. M., 1982. Petrography: An Introduction to the Study of Rocks in Thin Sections: San Francisco (Freeman), $626 \mathrm{p}$.

Date of initial receipt: 6 March 1991

Date of acceptance: 22 November 1991

Ms 127/128B-121 
APPENDIX

Framework Composition of Site 796, 797, and 799 Sandstone Samples

\begin{tabular}{|c|c|c|c|c|c|c|c|c|c|c|c|c|c|c|c|c|}
\hline Sample no. & $\begin{array}{l}\text { Depth } \\
\text { (mbsf) }\end{array}$ & Age & Qm & Qp & $\mathrm{Ch}$ & $P$ & $\mathrm{~S}$ & K & $\mathrm{R}_{\mathrm{v}}$ & $R_{p}$ & $\mathrm{R}_{\mathrm{m}}$ & $R_{s}$ & $\mathrm{Rc}$ & M & $\mathrm{Hv}$ & $\mathbf{R}_{\mathbf{i}}$ \\
\hline \multicolumn{17}{|l|}{ Hole 796B } \\
\hline $11 R-1-8$ & 252.8 & 1. Miocene & 1.4 & 0.5 & 0.5 & 21.0 & 0.2 & - & 67.9 & - & 0.2 & - & 2.3 & 0.2 & 6.0 & 0.3 \\
\hline $11 R-1-26$ & 253.0 & " & - & 0.3 & - & 22.8 & - & - & 72.8 & - & - & - & 0.5 & - & 3.7 & - \\
\hline $11 R-1-41$ & 253.1 & $"$ & 0.6 & - & - & 26.4 & - & - & 67.5 & - & - & - & 1.1 & - & 4.4 & - \\
\hline $11 R-1-62$ & 253.3 & $"$ & 1.3 & 0.3 & 0.5 & 33.4 & - & - & 61.0 & - & 0.5 & - & 2.8 & - & 0.3 & - \\
\hline $11 \mathrm{R}-2-43$ & 254.6 & $"$ & 1.6 & 0.2 & 1.2 & 20.0 & - & - & 56.2 & - & 0.2 & - & 17.9 & 0.2 & 1.4 & 0.9 \\
\hline $11 \mathrm{R}-2-131$ & 255.5 & $"$ & 0.4 & - & 0.8 & 18.7 & - & - & 55.1 & - & 0.4 & - & 22.1 & 0.4 & 0.8 & 1.5 \\
\hline $12 \mathrm{R}-2-120$ & 265.0 & $"$ & - & - & - & 33.1 & - & - & 63.0 & - & - & - & - & - & 1.7 & 2.2 \\
\hline 16R-CC-8 & 310.6 & $"$ & 0.4 & - & - & 27.8 & - & - & 68.2 & - & 0.4 & - & 2.9 & $=$ & - & 0.4 \\
\hline $17 R-1-73$ & 311.4 & $"$ & 0.4 & - & - & 39.2 & - & - & 54.0 & - & - & - & 3.0 & 0.8 & 1.1 & 1.5 \\
\hline $18 R-4-129$ & 326.2 & $"$ & - & 1.1 & - & 83.8 & - & - & 9.0 & - & - & - & 2.2 & 0.4 & 2.9 & 0.7 \\
\hline $23 R-1-13$ & 368.2 & $"$ & 0.7 & - & - & 9.5 & 0.7 & - & 78.6 & - & - & - & 9.5 & - & 0.7 & 0.3 \\
\hline $25 \mathrm{R}-1-55$ & 388.0 & $"$ & - & - & - & 15.9 & 0.4 & - & 83.7 & - & - & - & $\cdot$ & - & - & - \\
\hline $26 \mathrm{R}-2-58$ & 399.2 & $"$ & - & - & - & 21.9 & - & - & 73.3 & - & - & - & 4.5 & - & - & 0.4 \\
\hline 28R-1-34 & 416.8 & $"$ & 0.3 & - & 0.5 & 19.1 & - & - & 51.2 & - & - & - & 28.4 & - & - & 0.5 \\
\hline $19 R-4-103$ & 661.6 & e. Miocene & 7.9 & 2.2 & 2.2 & 9.3 & 3.1 & 0.4 & 21.2 & - & - & 1.4 & 36.6 & 1.8 & 0.9 & 13.2 \\
\hline \multicolumn{17}{|l|}{ Hole 797C } \\
\hline $22 \mathrm{R}-2-22$ & 686.8 & $"$ & 10.8 & 4.0 & 1.4 & 17.7 & 2.0 & - & 28.5 & 1.1 & - & - & 7.1 & 6.6 & 1.1 & 19.7 \\
\hline $22 R-2-84$ & 687.4 & $"$ & 8.3 & 1.1 & 1.1 & 13.3 & 1.7 & - & 60.9 & - & 0.3 & 1.1 & 5.0 & 3.3 & 0.6 & 3.3 \\
\hline $22 \mathrm{R}-3-24$ & 688.3 & $"$ & 4.3 & 0.4 & - & 8.7 & 3.5 & - & 74.6 & - & 0.7 & 1.1 & 0.4 & 4.1 & 1.3 & 0.9 \\
\hline $22 \mathrm{R}-3-70$ & 688.8 & $"$ & 9.4 & 1.4 & 2.1 & 6.6 & 6.4 & - & 69.4 & - & 0.2 & - & - & 3.3 & 1.2 & - \\
\hline $22 R-4-69$ & 690.3 & $"$ & 7.1 & 3.2 & 5.8 & 11.6 & 11.3 & 0.8 & 49.3 & - & 2.1 & 2.1 & - & 3.4 & 1.8 & 1.6 \\
\hline $22 R-6-3$ & 692.6 & $"$ & 6.0 & 2.1 & 1.9 & 6.9 & 9.3 & 1.9 & 65.1 & - & - & 3.2 & - & 2.3 & 0.5 & 0.9 \\
\hline 22R-6-99 & 693.6 & $"$ & 12.6 & 0.8 & 0.3 & 9.3 & 4.7 & - & 59.1 & - & - & 0.6 & - & 8.8 & 1.4 & 2.5 \\
\hline $23 R-1-47$ & 695.1 & $"$ & 8.8 & 1.4 & 0.2 & 7.0 & 3.5 & - & 67.5 & - & 2.3 & - & 3.3 & 4.2 & 1.2 & 0.7 \\
\hline $23 R-1-100$ & 695.6 & $"$ & 10.0 & 4.3 & 1.6 & 9.7 & 5.7 & 0.5 & 33.5 & 1.4 & - & 0.3 & 18.1 & 3.8 & 1.4 & 9.7 \\
\hline $23 \mathrm{R}-3-22$ & 697.8 & $"$ & 9.9 & 3.6 & 4.3 & 6.1 & 8.1 & - & 60.0 & $\therefore$ & 0.9 & - & 0.7 & 3.8 & 2.7 & - \\
\hline $23 R-3-69$ & 799.8 & $"$ & 7.6 & 3.8 & 1.6 & 8.5 & 16.4 & 1.1 & 38.4 & 1.1 & 1.1 & 1.9 & 11.4 & 3.8 & 1.4 & 1.9 \\
\hline $23 R-4-89$ & 700.0 & " & 10.3 & 3.7 & 0.9 & 21.1 & 8.4 & - & 34.8 & - & - & 0.9 & 6.2 & 5.0 & 0.6 & 8.1 \\
\hline $23 R-4-138$ & 700.5 & $n$ & 11.4 & 6.4 & 1.5 & 17.1 & 9.5 & 0.4 & 20.8 & 0.8 & - & 1.1 & 8.0 & 8.3 & 1.1 & 13.6 \\
\hline $25 R-1-73$ & 714.3 & $"$ & 4.9 & 2.1 & - & 9.7 & 4.2 & 0.2 & 69.4 & - & 0.7 & - & 1.6 & 4.2 & 2.8 & 0.2 \\
\hline $25 R-1-139$ & 715.0 & $"$ & 3.0 & - & 0.3 & 10.7 & 6.5 & - & 74.3 & - & - & - & - & 3.5 & 1.0 & 0.8 \\
\hline $25 R-2-16$ & 715.3 & $"$ & 7.8 & 1.3 & 3.2 & 14.6 & 8.7 & 0.7 & 37.5 & - & 0.3 & - & 14.9 & 7.8 & 0.3 & 2.9 \\
\hline $25 \mathrm{R}-3-56$ & 717.2 & $"$ & 6.3 & 4.7 & 6.1 & 6.5 & 3.0 & - & 67.0 & - & 2.1 & - & 0.5 & 2.8 & 1.2 & - \\
\hline $25 R-3-82$ & 717.4 & $"$ & 6.9 & 0.8 & 1.5 & 12.6 & 8.1 & 0.8 & 51.7 & - & 1.2 & - & 12.3 & 1.9 & 0.8 & 1.5 \\
\hline $25 R-4-83$ & 718.9 & $"$ & 5.1 & 0.8 & - & 1.6 & 2.1 & - & 86.7 & - & - & - & 0.5 & 2.7 & 0.3 & 0.3 \\
\hline 25R-6-78 & 721.9 & $"$ & 6.1 & 1.2 & 0.6 & 8.2 & 1.8 & - & 10.6 & - & 0.6 & - & 64.9 & 3.9 & 0.3 & 1.8 \\
\hline $30 R-4-62$ & 759.1 & $"$ & 5.5 & 1.0 & 0.3 & 13.3 & 5.3 & - & 64.8 & - & 0.3 & - & 6.3 & 1.5 & 1.5 & 0.5 \\
\hline $31 \mathrm{R}-5-37$ & 769.4 & " & 7.3 & - & - & 13.7 & 7.0 & 0.3 & 66.5 & - & - & - & 3.4 & 1.1 & 0.8 & - \\
\hline $33 \mathrm{R}-2-2$ & 783.1 & $"$ & 7.4 & 3.2 & 2.5 & 9.7 & 15.8 & - & 54.0 & - & 0.3 & 1.7 & - & 1.2 & 4.0 & 0.3 \\
\hline $33 R-2-115$ & 784.3 & " & 7.4 & 3.8 & 1.0 & 26.2 & 12.8 & 0.3 & 27.2 & - & 0.3 & - & 13.4 & 3.2 & 0.6 & 3.8 \\
\hline $33 R-3-5$ & 784.6 & $"$ & 5.7 & 0.3 & 0.3 & 12.5 & 11.9 & - & 61.8 & - & 0.3 & - & 3.0 & 1.6 & 0.8 & 1.9 \\
\hline $34 R-2-64$ & 793.1 & $"$ & 4.4 & 1.3 & - & 27.4 & 3.2 & - & 5.4 & - & 0.3 & - & 50.5 & 1.6 & - & 6.0 \\
\hline $34 R-3-15$ & 794.2 & $"$ & 4.8 & 6.4 & 1.2 & 18.5 & 6.4 & - & 49.8 & - & 0.4 & 2.8 & 6.8 & 0.4 & 0.8 & 1.6 \\
\hline $34 \mathrm{R}-3-89$ & 794.9 & $"$ & 4.5 & 1.1 & 1.4 & 17.2 & 5.7 & - & 64.7 & - & 0.6 & - & 0.9 & 1.1 & - & 2.8 \\
\hline $34 \mathrm{R}-3-122$ & 795.2 & $"$ & 7.8 & 0.9 & 2.3 & 31.1 & 3.2 & 0.5 & 37.9 & - & 0.9 & 0.5 & 11.0 & 2.7 & 0.9 & 0.5 \\
\hline $34 R-4-67$ & 796.2 & $"$ & 6.9 & 1.6 & 4.1 & 35.1 & 2.5 & - & 27.0 & 2.5 & 1.3 & 0.3 & - & 1.9 & 0.3 & 16.6 \\
\hline $34 R-5-26$ & 797.3 & $"$ & 3.2 & 2.2 & 0.4 & 14.0 & 2.5 & - & 14.4 & - & - & - & 60.4 & 2.9 & - & - \\
\hline $34 R-6-4$ & 798.5 & $"$ & 10.5 & 2.6 & 1.5 & 50.8 & 2.6 & - & 21.6 & - & - & 0.8 & 0.8 & 3.0 & 0.8 & 5.2 \\
\hline $34 R-6-103$ & 799.5 & $"$ & 3.5 & 3.5 & 2.4 & 22.7 & 3.0 & - & 59.9 & 0.3 & - & 1.2 & 5.0 & 1.5 & 0.6 & 1.5 \\
\hline $34 R-7-55$ & 800.6 & $"$ & 7.3 & 0.7 & - & 12.5 & 5.9 & - & 38.9 & - & . & 0.7 & 6.9 & 7.3 & 1.7 & 18.1 \\
\hline $36 R-3-109$ & 808.9 & $"$ & 8.9 & 1.3 & 0.7 & 24.3 & 5.6 & - & 20.1 & - & - & - & 28.0 & 10.9 & 0.3 & - \\
\hline $37 R-2-48$ & 816.4 & $"$ & 8.1 & 1.8 & - & 8.1 & 4.4 & 1.0 & 5.5 & . & - & - & 65.1 & 1.0 & 0.8 & 4.2 \\
\hline $37 R-3-84$ & 818.2 & $"$ & 6.5 & 3.6 & 3.6 & 9.7 & 8.5 & 0.2 & 45.9 & - & 0.5 & - & 15.7 & 3.7 & 1.7 & 0.5 \\
\hline $37 R-3-136$ & 818.8 & $"$ & 11.1 & 6.3 & - & 13.2 & 15.6 & 1.1 & 49.9 & - & 1.1 & - & - & 1.6 & 0.3 & - \\
\hline $37 R-5-58$ & 821.0 & $"$ & 7.3 & 1.5 & 2.4 & 25.2 & 1.2 & - & 50.2 & 0.9 & 0.3 & 0.3 & 3.7 & 1.5 & 0.3 & 5.2 \\
\hline $37 R-6-1$ & 821.9 & $"$ & 5.8 & 1.3 & 3.1 & 21.2 & 3.1 & - & 41.6 & 2.1 & 0.8 & - & 1.6 & 1.6 & 1.6 & 16.2 \\
\hline $41 R-1-108$ & 853.5 & $"$ & 9.7 & 0.3 & 0.8 & 16.7 & 4.3 & - & 56.3 & $\because$ & 2.4 & - & 2.2 & 4.0 & 2.4 & 0.8 \\
\hline $41 R-2-87$ & 854.8 & $"$ & 9.9 & 2.9 & 2.7 & 30.2 & 1.6 & 1.6 & 40.6 & 1.1 & 2.7 & 1.1 & - & 2.9 & 0.2 & 2.7 \\
\hline \multicolumn{17}{|l|}{ Hole 799B } \\
\hline $61 R-1-100$ & 1020.8 & e. Miocene & 32.6 & 7.5 & - & 24.2 & - & 18.0 & 3.4 & 3.4 & - & - & 7.1 & 1.2 & 0.6 & 1.9 \\
\hline $61 R-2-135$ & 1022.9 & $"$ & 22.7 & 4.7 & 0.3 & 31.0 & - & 18.4 & 4.7 & 8.8 & - & 3.3 & 4.1 & 1.6 & - & 0.5 \\
\hline $61 R-3-131$ & 1024.1 & $"$ & 27.1 & 7.2 & - & 20.6 & 3.5 & 11.6 & 7.0 & 1.5 & 1.1 & 12.7 & 4.4 & 1.3 & 0.4 & 1.5 \\
\hline $61 R-4-138$ & 1025.7 & $"$ & 27.1 & 6.6 & 0.3 & 18.4 & 0.6 & 14.3 & 2.7 & 9.3 & - & 8.0 & 8.0 & 3.3 & - & 1.4 \\
\hline $62 R-3-98$ & 1033.5 & $"$ & 36.9 & 5.9 & 0.5 & 27.0 & - & 14.0 & 4.0 & 6.0 & - & 3.5 & 1.3 & 0.5 & - & 0.5 \\
\hline $62 R-4-13$ & 1034.1 & $"$ & 27.1 & 8.6 & 0.3 & 22.6 & - & 13.7 & 3.1 & 15.4 & - & 6.9 & - & 0.3 & - & 2.0 \\
\hline $64 \mathrm{R}-\mathrm{CC}-14$ & 1058.3 & $"$ & 27.2 & 6.9 & 0.8 & 22.0 & 0.3 & 20.6 & 1.1 & 10.2 & 1.1 & 4.7 & 2.2 & 0.3 & - & 2.7 \\
\hline $65 R-2-146$ & 1061.4 & $"$ & 32.1 & 7.9 & 0.6 & 19.8 & 0.6 & 22.2 & 1.8 & 2.0 & - & 5.3 & 5.3 & 0.6 & 0.3 & 1.7 \\
\hline $67 R-1-72$ & 1078.4 & $"$ & 35.3 & 6.6 & 0.8 & 18.7 & 1.7 & 29.1 & 1.2 & 0.4 & - & 4.1 & - & 0.4 & - & 1.7 \\
\hline $67 R-3-59$ & 1081.3 & $"$ & 27.7 & 4.7 & 0.3 & 25.4 & 1.6 & 20.2 & 2.9 & 6.5 & 0.5 & 4.5 & 2.9 & 0.5 & 0.3 & 2.1 \\
\hline
\end{tabular}

